\title{
Jurisdicción internacional y derecho aplicable al reaseguro en Argentina ${ }^{12}$
}

\author{
María Blanca Noodt Taquela ${ }^{3}$
}

\section{REGULACION DEL REASEGURO EN ARGENTINA}

\section{1. - Desregulación del Reaseguro}

A partir de 1989, comenzó en Argentina un proceso de desregulación de la economía, a través de las leyes 23.696 de Reforma del Estado, que autorizó la privatización de numerosas empresas del Estado y 23.697 de Emergencia Económica y del decreto 2284/ 91, del 31 de octubre de $1991^{4}$, que tuvo por objeto desregular distintos mercados.

En esta línea de política legislativa se produce entre 1991 y 1992 la liberación de la actividad reaseguradora que había estado monopolizada en Argentina por el Estado durante varias décadas.

Las compañías argentinas de seguros estaban obligadas a ceder el total del excedente de su propia retención al Instituto Nacional de Reaseguros - INDER - empresa del Estado, creada en 1953 y las compañías de seguros extranjeras que actuaban en el país, debían ceder al menos el $30 \%$ de los riesgos generales y personales que contratasen en Argentina (arts. 4 y 5 del Estatuto orgánico del INDER, decreto 10.073/53, del 9 de junio de 1953).

\footnotetext{
${ }^{1}$ Agradezco a los Dres. Héctor A. Perucchi, Carlos M. Schwarzberg y Roberto A. Vicario el material que tan amablemente me facilitaron sobre el tema.

2 Publicado en Revista de Derecho de Seguros, Madrid, julio-septiembre de 1998, n 95, pp. 385-421 y próximamente en Revista de Transportes y Seguros, Montevideo, Fundación de Cultura Universitaria, $n^{0}$ 12, 1999.

${ }^{3}$ Professora de Derecho Internacional Privado de la Universidad de Buenos Aires y de la Universidad de Morón y de Derecho del Comercio Internacional en el Mercosur en el Prosgrado de la Universidad de Buenos Aires.

${ }^{4}$ El decreto $2284 / 91$ fue ratificado por el art. 29 de la ley 24.307 del 23 de diciembre de 1993.
} 
El INDER podía autorizar a las compañías argentinas de seguros a reasegurar en empresas privadas argentinas o extranjeras, en aquellos ramos en que el INDER no podía o no consideraba conveniente operar (art. 8). ${ }^{5}$

En 1991 se autoriza la liberación del 40\% de las cesiones de reaseguros, y a partir del 1 o de enero de 1992 se deja sin efecto totalmente el régimen de cesión obligatoria de reaseguros al INDER y se declara la disolución del organismo estatal (arts. 1 y 2 del decreto 171/92, dictado el 23 de enero de 1992).

\section{2.- Normas sobre Reaseguro}

La ley de seguros 17.418 , sancionada el 30 de agosto de 1967, en vigencia desde el 1 de julio de 1968, contiene unas pocas normas sobre reaseguro, en el Título II de la ley (arts. 159 a 162).

El art. 159 dispone que el Título II de la ley es aplicable a los contratos de reaseguro y a los de retrocesión.

El art. 160 de la ley 17.418 establece, en caso de liquidación forzosa del asegurador, el privilegio de la masa de asegurados sobre el saldo acreedor que arroje la cuenta del asegurador con el reasegurador, norma idéntica al art. 78 de la ley española de $1980 .{ }^{6}$

El art. 161 establece la compensación de deudas y créditos recíprocos del asegurador y reasegurador, en caso de liquidación voluntaria o forzosa de uno u otro.

Por último, el art. 162 dispone que el contrato de reaseguro se rige por las disposiciones de este Título y las convenidas por las partes.

Este art. 162 ha sido interpretado en el sentido de que no son de aplicación automática al contrato de reaseguro las normas sobre seguros contenidas en el Título I de la ley 17.418. Según Halperín y Morandi, al reaseguro le son preponderantemente aplicables las normas contractuales convenidas por las partes en el respectivo contrato y recién y en forma supletoria se le aplicarían las normas del Título I de la ley de seguros. En el mismo sentido se pronuncia López Saavedra, quien destaca que la aplicación supletoria de los principios contenidos en el Titulo I de la ley, los será en la medida en que no atenten o desvirtúen la esencia y funcionalidad del sistema".?

\footnotetext{
${ }^{5}$ HALPERIN, Isaac Seguros. Exposición crítica de la ley 17.418, Buenos Aires, Depalma, 1970, págs. 89-90.

${ }^{6}$ HILL, María Concepción El reaseguro, Barcelona, Bosch, 1995, págs. 142-143.

${ }^{7}$ HALPERIN, op. cit., pág. 82; LOPEZ SAAVEDRA, Domingo L. "Algunos conceptos sobre el contrato de reaseguro", en Revista Mercado Asegurador, Buenos Aires, vol. 189, enero-febrero 1995, págs: 35-39, pág. 39; LOPEZ SAAVEDRA, Domingo L. "El contrato de reaseguro: naturaleza juridica", en Revista Mercado Asegurador, Buenos Aires, septiembre de 1992, págs. 18 y siguientes; LOPEZ SAAVEDRA, Domingo L. "Algunos aspectos del contrato de reaseguro", en Revista La Ley, Buenos Aires, tomo 1994-E, págs. 934-942, espec. pág. 941.
} 
Perucchi destaca que sería conveniente una mención expresa en la ley sobre la aplicación del título I, al reaseguro, pues algunos fallos interpretaron lo contrario. ${ }^{8}$

No rige para el reaseguro el carácter imperativo de las normas mencionadas en el art. 158 de la ley de seguros, que no pueden ser dejadas de lado por voluntad de las partes. Por ejemplo, la prohibición de incluir cláusulas compromisorias en la póliza, establecida en el art. 57 de la ley 17.418.

La ley 20.091, de Entidades de seguros y su control, sancionada el 11 de enero de 1973, regula la actividad aseguradora y reaseguradora en todo el territorio de la Nación y la somete al contralor de la Superintendencia de Seguros de la Nación. Se considera comprendido el reaseguro en la ley, "en tanto no resulte afectado el régimen legal de reaseguro en vigencia" ( art. 1, segundo párrafo).

\section{3.- Resolución 24.805 de 1996 de la Superintendencia de Seguros}

La reglamentación de la Superintendencia de Seguros de la Nación, ha sufrido una sustancial modificación, a partir de la desregulación del reaseguro en 1992. Actualmente, la actividad reaseguradora se encuentra reglamentada por la resolución. 24.805, del 13 de septiembre de 1996 de la Superintendencia de Seguros de la Nación, que unificó normas anteriores dictadas a partir de 1991, con muy leves modificaciones y derogó las resoluciones anteriores. ${ }^{9}$

La resolución 24.805 , que unifica el sistema vigente, distingue las reaseguradoras nacionales, las sucursales de reaseguradoras extranjeras, las reaseguradoras extranjeras y los intermediarios de reaseguros (brokers), ya sean nacionales o extranjeros. ${ }^{10}$

a) Reaseguradoras nacionales son las constituidas y domiciliadas en Argentina (art. 19), que tengan por objeto exclusivo operar en reaseguros (art. 1. a). Deben necesariamente adoptar la forma de sociedad anónima, cooperativa o mutual (art. 1.a).

b) Sucursales o agencias establecidas en Argentina de reaseguradoras extranjeras o de agrupaciones de estas (art. 1.b). Hay que entender por reaseguradoras extranjeras las constituidas en el extranjero o las constituidas en Argentina, que tengan domicilio en el extranjero, por interpretación a contrario de la calificación de persona jurídica nacional del art. 19. Las sucursales o agencias tienen que cumplir con los requisitos

\footnotetext{
8PRUCCHI, Héctor A. "Derecho de reaseguros. 1". Nota", en Gaceta del Seguro, Buenos Aires, $n^{\circ}$ 1, febrero de 1994, págs. 5-8, espec. pág. 5, quien sostiene que la citación en garantía del asegurador (art. 118 de la ley 17.418) es inaplicable al reaseguro. MORANDI, Juan Carios $F$., STEINFELD, Eduardo R., PERUCCHI, Héctor, PANTANALI, Norberto J. y QUINTANA, Enrique J. "Modificación del título II de la ley 17.418", Ponencia presentada en las "II Jornadas sobre Política....", op. cit., pág. 172-179, espec. pág. 178.

'La resolución derogada 23.881 de 1995 era similar al régimen vigente Dicha resolución había a su vez derogado la resoluciones 21.099, 21.193, 21.212 y 22.559, todas de la Superintendencia de Seguros de la Nación.

${ }^{10}$ LOPEZ SAAVEDRA, Domingo M. "Nueva Resolución de la S.S.N. sobre la contratación de reaseguros", en Revista Mercado Asegurador, Buenos Aires, vol. 193, junio de 1995, págs. 34-36.
} 
del art. 118, tercer párrafo de la ley 19.550 de 1972, de sociedades comerciales, para inscribirse en la Inspección General de Justicia en la ciudad de Buenos Aires o Registro Público de Comercio de la provincia respectiva. Además tienen que estar autorizadas para funcionar por la Superintendencia de Seguros de la Nación (art. 5 de la ley 20.091).

c) Aseguradoras autorizadas para operar en Argentina, ya sean nacionales o sucursales de aseguradoras extranjeras (art. 1, c).

d) Reaseguradoras extranjeras inscriptas en Argentina (art. 5).

e) Reaseguradoras extranjeras no inscriptas en Argentina, cuando interviene un corredor de reaseguro habilitado (art. 8).

f) Intermediarios de reaseguros, ya sean personas físicas o jurídicas, nacionales o extranjeras, inscriptos en Argentina (art.9).

Las reaseguradoras nacionales y las sucursales de las reaseguradoras extranjeras a fin de inscribirse en la Superintendencia deben obtener la autorización para funcionar y cumplir con las normas sobre capitales mínimos (puntos 30.1.2. y 30.1.4. de la Resolución General 21.523 de la Superintendencia de Seguros de la Nación, del 2 de enero de 1992) (art. 2 de la resolución 24.805).

En ambos casos, la reglamentación les exige básicamente a ambos tipos de reaseguradores, de acuerdo a los arts. 3 y 6 de la resolución 24.805 :

a) Comunicar dentro de los 30 días cualquier variación que experimente la entidad respeto a los antecedentes acompañados con su inscripción.

b) Entregar a la cedente dentro de los 30 días de la vigencia del reaseguro respectivo el "contrato de reaseguro o en su defecto las notas de cobertura", en el último supuesto, el contrato debe entregarse dentro de los seis meses del momento de inicio de vigencia del mismo.

c) Informar a la Superintendencia dentro de los 30 días de producidas "las anulaciones o rescisiones de los contratos de reaseguro celebrados", como así también los siniestros superiores a u\$s 100.000 rechazados por el reasegurador:

d) Informar cualquier variación en la política de suscripción o toda decisión que reduzca la cobertura o afecte el normal cumplimiento del contrato.

Además las reaseguradoras extranjeras deben también acreditar que cuentan con un patrimonio neto no inferior a US $\$ 30.000 .000$, designar un apoderado con amplias facultades administrativas y judiciales, incluso para ser emplazado en juicio, quien deberá constituir domicilio en la ciudad de Buenos Aires, en el cual valdrán todas las notificaciones.

Una vez inscriptas las reaseguradoras extranjeras deberán presentar anualmente sus balances con un informe de auditor independiente, notificar los cambios de mandatario y remitir a la Superintendencia de Seguros de la Nación la información que ésta requiera respecto de los contratos suscriptos.

Los intermediarios o corredores de seguros para poder actuar como tales, ya sean personas físicas o jurídicas, nacionales o extranjeras, deben inscribirse en el Registro que lleva la Superintendencia de Seguros de la Nación (art. 9 de la tesolución 24.805).

Para ello se les exige la contratación de un seguro de "errores y omisiones" por un monto 
mínimo de US $\$ 1.000 .000$, con una franquicia máxima de u\$s 50.000 , y la presentación de una declaración jurada por la que se comprometen a colocar los reaseguros en los que intermedie en entidades que puedan pagar en moneda de libre convertibilidad (art. 9 incs, a. y b.).

Si se trata de sociedades extranjeras deben acreditar su existencia legal de acuerdo a la ley del país de constitución y donde mantengan la sede principal de sus actividades y la autorización para intermediar en los riesgos cedidos (art. 9 inc. d, punto I). Además deben designar un apoderado con facultades amplias, incluso para ser emplazado en juicio, que debe constituir domicilio en la República Argentina, donde valdrán todas las notificaciones (art. 9 inc. d, punto II). ${ }^{11}$

\section{II. - JURISDICCION INTERNACIONAL JUDICIAL}

\section{PROTOCOLO DE BUENOS AIRES. MERCOSUR}

El proceso de integración del Mercosur, iniciado con el Tratado para la constitución de un Mercado Común entre la República Argentina, la República Federativa del Brasil, la República del Paraguay y la República Oriental del Unuguay, suscripto en Asunción, Paraguay, el 26 de marzo de 1991, ha venido desarrollando un proceso de codificación del Derecho Internacional Privado casi desde sus inicios.

Además de enfocar casi todos los aspectos de la cooperación judicial internacional, el Mercosur ha regulado la jurisdicción internacional en materia contractual en el Protocolo sobre jurisdicción intemacional en materia contractual, suscripto en Buenos Aires, el 5 de agosto de 1994, que se encuentra vigente entre Argentina, Brasil y Paraguay. ${ }^{12}$

\section{a) Ambito de aplicación material y espacial. Aplicación con respecto a terceros países \\ El Protocolo de Buenos Aires no se aplica a los contratos de trabajo, de venta a consumidores, de transporte, de seguros, ni a los acuerdos celebrados en materia de}

\footnotetext{
"LOPEZ SAAVEDRA "Nueva Resolución de la S.S.N. sobre la contratación de reaseguros", op. cit, pág. 34.

${ }_{12}$ El Protocolo de Buenos Aires fue adoptado por el Consejo Mercado Común (C.M.C.), por decisión 1/94. Argentina lo aprobó por ley 24.669 de 1996 y fue ratificado por Argentina, Brasil y Paraguay. Al 1 de septiembre de 1998 no había sido ratificado por Uruguay. Sobre el Protocolo de Buenos Aires, ver: PALLARES, Beatriz "Jurisdicción internacional en el Mercosur", en Revista de la Facultad de Ciencias Jurídicas y Sociales de la Universidad Nacional del Litoral, Santa $\mathrm{Fe}, \mathrm{n}^{\circ}$ 123, 1995, págs. 179-194; TELLECHEA BERGMAN, Eduardo "Un marco jurídico al servicio de la integración. Las regulaciones del Mercosur sobre Jurisdícción Internacional", en CASELLA, Paulo Borba Contratos Internacionais e Direito Econômico no MERCOSUL, Sao Paulo, Editora LTr, 1996 , págs. 48-74; NOODT TAQUELA, María Blanca "Los acuerdos de elección de foro en el Protocolo de Buenos Aires de 1994" en "Mercosur. Balance y Perspectivas", Montevideo, Fundación de Cultura Universitaria, 1996, págs. 135-149 y en Revista Jurisprudencia Argentina, Buenos Aires, 1996- II, págs. 738-747.
} 
concursos y quicbras, derecho de familia y sucesiones, seguridad social, detechos reales, ni contratos administrativos (art, 2).

Considero que debe aplicarse al reaseguro, porque las razones que determinan la exclusión del contrato de seguro no se encuentran presentes en el reaseguro. La modalidad de contratación del seguro, típicamente por adhesión, la existencia de condiciones generales y la necesidad de proteger a la parte más débil del contrato no aparecen por cierto, en el reaseguro. Por ello, tal como sucede con la Convención relativa a la competencia judicial y a la ejecución de resoluciones judiciales en materia civil y comercial, suscripta en Bruselas el 27 de septiembre de 1968, que contiene normas especiales para el contrato de seguro (arts. 7 a 12), que no resultan aplicables al reaseguro ${ }^{13}$, entiendo que el Protocolo de Buenos Aires debe aplicarse para determinar la jurisdicción internacional en materia de contratos de reaseguros.

Es importante destacar que el Protocolo de Buenos Aires rige la jurisdicción internacional en materia de reaseguros no sólo cuando ambas partes están domiciliadas en. Estados Parte del Mercosur (art. 1. a), sino también cuando una sola de ellas está domiciliada en un Estado Parte del Mercosur, si se ha pactado la jurisdicción de un país del Mercosur y existe una conexión razonable (art. 1.b).

En cambio, el Protocolo no se aplica para determinar la jurisdicción internacional entre una parte domiciliada en el Mercosur y otra parte domiciliada en terceros Estados, cuando se pacta la jurisdicción de un Estado no parte del Mercosur o cuando no se pacta la jurisdicción. En estos casos deberá acudirse a las normas de jurisdicción internacional de fuente interna de cada uno de los países. ${ }^{14}$

\section{b) Autonomía de la voluntad. Acuerdos de elección de foro. Prórroga post- litem}

El Protocolo de Buenos Aires de 1994 permite pactar los tribunales competentes en los contratos internacionales (art. 4), con lo que soluciona el problema que se presentaba anteriormente, ya que los países del Mercosur, con excepción de Argentina, carecen de norma de fuente interna que permita los acuerdos de elección de foro o contienen una norma que los prohibe expresamente.

El Protocolo de Buenos Aires exige que el acuerdo de elección de foro se realice por escrito y permite que se efectúe en el momento de la celebración del contrato o con posterioridad, incluso una vez surgido el litigio (arts. 4 y 5) Se invalidan los pactos obtenidos en forma abusiva (art. 4).

Se admite también la prórroga de jurisdicción posterior a la interposición de la

\footnotetext{
13 TIRADO ROBLES, Carmen La competencia judicial en la Unión Europea. Comentarios al Convenio de Bruselas, Barcelona, Bosch, 1995, pág. 74.

${ }_{14}$ NOODT TAQUELA, María Blanca «Los acuerdos de elección de foro..."', op. cit., Montevideo, págs 138-142; Buenos Aires, págs. 740-742.
} 
demanda, si el demandado la admite en forma positiva y no ficta, es decir si el demandado comparece sin cuestionar la jurisdicción, pero no si se lo declara rebelde (art. 6). Esta norma otorga primacía a la sumisión tácita posterior a la iniciación de la demanda, respecto al pacto de jurisdicción escrito. ${ }^{15}$

Supongamos una cláusula atributiva de jurisdicción a favor de los tribunales de Río de Janeiro, en un contrato celebrado entre una empresa domiciliada en Argentina y otra en Brasil. La empresa argentina promueve la demanda en Argentina. No corresponde que el juez argentino se declare de oficio incompetente por existir una jurisdicción exclusiva pactada por las partes por escrito.

Si el demandado no se presenta, el juez del Mercosur carece de una norma expresa al estilo del art. 20 de la Convención de Bruselas de 1968, que lo obligue a declarar su incompetencia después de la notificación de la demanda.

A pesar de ello, creo que una interpretación que torne operativo el art. 6 del Protocolo, requiere que el juez declare la falta de jurisdicción internacional después de haber notificado el traslado de demanda si el demandado no se presenta, porque no se configura cl supuesto de prórroga consentida en forma positiva por el accionado y cobra relevancia el acuerdo de clección de foro a favor de los tribunales de Brasil.

\section{c) Jurisdicción internacional en ausencia de elección}

Si no existe acuerdo de las partes, el Protocolo de Buenos Aires, cstablece varias jurisdicciones competentes en forma concurrente. En la práctica, podría decirse que serán competentes los tribunales de los domicilios de ambas partes, a elección del actor. No por que esté expresado así en el tratado, sino porque las cuatro conexiones establecidas en los arts. 7 y 11 , con las precisiones del art. 8, nos llevan a esa conclusión.

Las cuatro jurisdicciones previstas son: a) Lugar de cumplimiento de la obligación que sirve de base a la demanda (arts. 7. a y 8) ; b) Domicilio del demandado (arts. 7. b. y 9); c) Domicilio del actor, cuando demostrare que cumplió su prestación (art. 7.c); y d) Lugar de celebración del contrato por parte de personas jurídicas demandadas, cuya sede se encuentre en otro Estado Parte (que coincidirá generalmente con el domicilio del actor) (art. 11).

No existen normas en el Protocolo de Buenos Aires para prevenir o evitar el forum shopping.

\footnotetext{
${ }^{15}$ Se receptó la interpretación dada por el T.J. C.E. en 1981 en el caso "Elefanten", a la relación existente entre los arts. 17 y 18 de la Convención de Bruselas de 1968. T.J.C.E., sentencia del 24 de junio de 1981, "Elefanten Schuh GmbH c/ Pierre Jacqmain, asunto 150/80, en Recueil 1981, pág. 1671 y ss, y comentario de H. Gaudemet-Tallon en Revue critique de droit international privé, 1982-1, pág. 152 y ss, Ver sintesis en TIRADO ROBLES, Carmen La competencia judicial en la Unión Europea. Comentarios al Convenio de Bruselas, Barcelona, Bosch, 1995, págs. 363. 365.
} 


\section{2.- TRATADOS DE MONTEVIDEO DE 1940}

a) Rechazo de la autonomía de la voluntad. Interpretaciones diferentes. Prórroga post-litem

La falta de ratificación hasta el momento del Protocolo de Buenos Aires por parte de Uruguay, hace aplicable en las relaciones de ese país con Argentina y Paraguay, el art. V del Protocolo Adicional a los Tratados de Montevideo de 1940, que impide pactar la jurisdicción, salvo que la prórroga sea admitida por el demandado voluntariamente una vez interpuesta la demanda, como lo autoriza el art. 56, último párrafo del Tratado de Derecho Civil Internacional de Montevideo de 1940.16

Se trata de la prórroga post-litem o sumisión tácita, que requiere la presentación en el juicio del demandado, sin cuestionar la jurisdicción. En casos de rebeldía, no opera la prórroga de jurisdicción.

En el momento actual sólo tendremos total scguridad sobre la jurisdicción en la cual se dirimirá un conflicto en el que se encuentre involucrada una parte domiciliada en Uruguay, si se pacta un acuerdo arbitral, cuya validez está admitida actualmente por los cuatro países del Mercosur. ${ }^{17}$

b) Jurisdicción internacional en ausencia de elección: principio del paralelismo y domicilio del demandado

Los Tratados de Montevideo de 1940 no contienen normas sobre jurisdicción internacional en materia de reaseguros, pero si sobre seguros. El art. 13 del Tratado de Derecho Comercial Terrestre Internacional de Montevideo de 1940 se refiere a seguros terrestre o sobre la vida y el art. 30 del Tratado de Navegación Comercial Internacional de Montevideo 1940, a los seguros marítimos.

¿Resultan aplicables estas normas sobre jurisdicción en materia de seguros al contrato de reaseguro? Lamentablemente no existe jurisprudencia, porque el monopolio estatal que imperó por décadas en los países latinoamericanos, por una parte, y la costumbre de pactar cláusulas arbitrales, por otra, hacen que no se registren casos de aplicación de estas normas, que además tienen un ámbito de aplicación espacial muy reducido.

La norma general en materia de acciones personales: art. 56 del Tratado de Derecho Civil Internacional de Montevideo de 1940, atribuye jurisdicción internacional a los jueces del Estado cuya ley resulta aplicable a la relación jurídica - principio del paralelismo - o a los jueces del domicilio del demandado. Será necesario entonces, determinar la ley aplicable al contrato de reaseguro para conocer el juez competente.

\footnotetext{
${ }_{16}$ El Tratado de Derecho Civil Internacional y el Protocolo Adicional fueron aprobados por Argentina por decreto-ley $7771 / 56$ y ratificados por Argentina, Paraguay y Uruguay.

17 Ver punto III.
} 
La ley aplicable al seguro de vida es la del Estado donde está domiciliada la compañía aseguradora o sus sucursales o agencias (art. 12 del mismo Tratado). En cuanto a los demás seguros terrestre, la ley aplicable es la del Estado donde están situados los bienes objeto del seguro a la época de su celebración (art. 12 del mismo Tratado), que puede implicar otra jurisdicción diferente a las del domicilio de la aseguradora o del domicilio del asegurado, aunque generalmente coincidirá con uno de ellos.

La ley aplicable a los seguros marítimos y aéreos es la del domicilio de la sociedad aseguradora o sus sucursales o agencias (arts. 28 y 43 del Tratado de Navegación Comercial Internacional de Montevideo 1940).

Si se aplica la norma general del art. 56 del Tratado de Derecho Civil Internacional de Montevideo de 1940 o si se considera regida la cuestión por el art. 13 del Tratado de Derecho Comercial Terrestre Internacional de Montewideo de 1940 no existe mucha diferencia respecto de las jurisdicciones competentes. En cualquiera de los casos tendrán competencia internacional los jueces cuya ley sea aplicable al contrato de reaseguro y los del domicilio del demandado. Pero si se considerara aplicable el art. 13 del Tratado de Derecho Comercial, puede demandarse además ante los jueces del domicilio del reasegurador o del asegurador (reasegurado), independientemente de quien sea demandado.

No existe diferencia en caso de reaseguros marítimos o aéreos si se aplica el art. 56 del Tratado de Derecho Civil Internacional de Montevideo de 1940 o si se rige la cuestión por el art. 30 del Tratado de Navegación Comercial Internacional de Montevideo 1940

Nos inclinamos por mantener la aplicación de la norma general del art. $56 \mathrm{del}$ Tratado de Derecho Civil, ya que la existencia de varios reaseguradores domiciliados en distintos países podría abrir demasiadas jurisdicciones, cuando muchas veces el asegurador contrata con un intermediario, sin saber a ciencia cierta quienes serán los reaseguradores.

De cualquier modo, cualquiera sea la postura que se sostenga, pienso que la prórroga post-litem autorizada por el art. 56, último párrafo del Tratado de Derecho Civil Internacional de 1940, será aplicable en todos los casos.

\section{3.- TRATADOS DE MONTEVIDEO DE 1889}

a) Autonomía de la voluntad. Silencio normativo e interpretaciones diferentes

Los Tratados de Montevideo de 1889 de Derecho Civil Internacional y de Derecho Comercial Internacional fueron ratificados por Argentina, Bolivia, Paraguay, Perú y Uruguay: Colombia adhirió posteriormente. Dado que Argentina, Paraguay y Uruguay ratificaron los respectivos Tratados de 1940, los Tratados de 1889 se aplican actualmente en las relaciones de los países ratificantes de los Tratados de 1940, con Bolivia, Colombia y Perú y también en las relaciones entre Bolivia, Colombia y Perú.

El silencio de los Tratados de Montevideo de 1889 respecto de la autonomía de la voluntad, no ha sido interpretado en forma pacífica.

La doctrina uruguaya en general considera que el silencio de los Tratados de 1889 
implica que no está permitido pactar la jurisdicción internacional, como tampoco la ley aplicable al contrato. ${ }^{18}$

Parte de la doctrina argentina, en particular Goldschmidt y Boggiano, entienden que el silencio debe ser interpretado como ausencia de prohibición y por ende aceptan la validez de los pactos de jurisdicción y de elección de la ley aplicable. ${ }^{19}$

b) Jurisdicción internacional en ausencia de elección: principio del paralelismo y domicilio del demandado

La atribución de jurisdicción internacional en el Tratado de 1889 es idéntica a la del Tratado de 1940, es decir se otorga a los jueces del Estado cuya ley resulta aplicable a la relación jurídica - principio del paralelismo - o a los jueces del domicilio del demandado. (art. 56 del Tratado de Derecho Civil Internacional de Montevideo de 1889), pero el Tratado de 1889 no contempla la prórroga post-litem.

El Tratado de Derecho Comercial Intemacional de Montevideo de 1889, en su art. 10, en materia de contratos de seguros, atribuye jurisdicción a los jueces del domicilio legal de las sociedades aseguradoras o de sus sucursales. La aplicación de esta norma al reaseguro, en el caso del Tratado de 1889 - a diferencia de lo que sucede en el Tratado de 1940. resul ta más limitativa de la jurisdicción internacional, que si se aplica la norma general del art. 56 del Tratado de Derecho Civil de 1889, ya que esta última norma permite demandar ante los jueces cuya ley es aplicable al contrato, que en este caso sería el país donde esté situado el bien objeto del seguro en la época de su celebración (art. 8 del Tratado de Derecho Comercial Internacional de 1889).

En cambio, en materia de seguro marítimo, el Tratado de Derecho Comercial Intemacional de 1889 no contiene norma sobre jurisdicción internacional, sino que se limita a indicar la ley aplicable (art. 9), por lo que debe recurrirse necesariamente para determinar el juez competente, al art. 56 del Tratado de Derecho Civil Intemacional.

\section{4.- SISTEMA DE FUENTE INTERNA ARGENTINO}

Las normas de fuente interna que rigen la jurisdicción internacional en materia contractual son el art. 1 del Código Procesal Civil y Comercial de La Nación, ley 17.454 de 1967, modificado por ley 21.305 de 1976 y actualmente por la ley 22.434 de 1981 y los arts. 1215 y 1216 del Código Civil de 1869.

Las normas de jurisdicción internacional sobre seguros marítimos son los arts. 620 y 621 de la ley 20.094 de Navegación, sancionada el 15 de enero de 1973.

\footnotetext{
18 FRESNEDO de AGUIRRE, Cecilla La autonomia de la voluntad en la contratación internacional, Montevideo, Fundación de Cultura Universitaria, 1991, págs. 51-54.

${ }^{19}$ GOLDSCHMIDT, Werner Derecho Internacional Privado, 4ª. ed., Buenos Aires, Depalma, 1982, parág. 314, pág. 391-392.
} 
No existen normas específicas de competencia internacional para el contrato de reaseguro. Por las razones que hemos expuesto con relación a las normas contenidas en tratados internacionales, consideramos que deben aplicarse las normas de jurisdicción sobre contratos en general y no las que se refieren al contrato de seguro marítimo.

El art. 16 de la ley 17.418 permite la prórroga de jurisdicción dentro del país y prohibe la constitución de domicilio especial.

\section{a) Autonomía de la voluntad. Suficiencia de la elección}

El art. 1 del Código Procesal Civil y Comercial de la Nación, autoriza los pactos de jurisdicción, en asuntos de índole patrimonial intemacionales. El pacto debe realizarse por escrito, al momento de celebrar el contrato o con posterioridad. No se permite la autonomía de la voluntad en casos de jurisdicción argentina exclusiva o cuando la prórroga esté prohibida por la ley. No existe tal prohibición en materia de reaseguros, ni puede considerarse que exista algún supuesto de jurisdicción exclusiva.

No se exige que la jurisdicción elegida tenga alguna conexión con el contrato, por lo que puede pactarse la jurisdicción de un Estado neutral. ${ }^{20}$

En materia de navegación, el art. 621 de la ley 20.094 permite solamente la prórroga de jurisdicción con posterioridad a la producción del hecho generador de la controversia. Carecen de virtualidad, entonces, los pactos de jurisdicción contenidos en los contratos de seguros.

El criterio receptado en este artículo había sido adoptado por la jurisprudencia argentina desde antiguo, a partir del fallo de la Corte Suprema de Justicia, del 16 de noviembre de 1936 en la causa "Compte c/ Ybarra", en la que se invalidó el pacto de jurisdicción contenido en el conocimiento de embarque. ${ }^{21}$

No consideramos aplicable el art. 621 de la ley de navegación a los contratos de reaseguro, por las razones que ya hemos explicado.

Tampoco consideramos aplicable al contrato de reaseguro el art. 16 de la ley 17.41822, contenido en el título I de la ley de seguros, por las mismas razones. Sin embargo, autores reconocidos en materia de seguros han sostenido la imposibilidad legal de pactar la jurisdicción internacional en materia de reaseguros; consideran aplicable al reaseguro el art. 16 de la ley 17.418 , entendiendo que la norma prohibe pactar la jurisdicción fuera del país en los contratos de reaseguro. ${ }^{23}$

\footnotetext{
${ }_{20}$ UZAL, María Elsa Solución de controversias en el comercio internacional, Buenos Aires, AdHoc, 1992, págs. 27-33.

${ }^{21}$ Corte Suprema de Justicia, 16 de noviembre de 1936 "Compte y Cía, Miguel c/ Ybarra y Cía" en Revista La Ley, Buenos Aires, tomo 4, págs. 925-941. Ver: CAPPAGLI, Alberto C. "A medio siglo de Compte c/ Ibarra", en Revista del Colegio de Abogados de Buenos Aires, Buenos Aires, año 1986, tomo XLVI, no 3, págs. 87-123.

${ }_{22} \mathrm{El}$ art. 16, primer párrafo de la ley 17.418 dispone: Se prohibe la constitución de domicilio especial. Es admisible la prórroga de la jurisdicción dentro del pais.

${ }^{23}$ PERUCCHI, Héctor A. "Algunos aspectos jurídicos del contrato de reaseguro" en V'a Jornadas Nacionales del Derecho del Seguro, Huerta Grande, Córdoba, Argentina, 1992, págs.111-122, espec. págs.117-118.
} 
No alcanzamos a comprender la razón para admitir la validez del acuerdo arbitral, y prohibir en cambio el pacto de jurisdicción en la esfera internacional. La autonomía de la voluntad se ejerce en forma mucho más amplia en el arbitraje internacional, que implica escapar de toda jurisdicción estatal, que cuando se tealiza un acuerdo de elección de foro a favor de tribunales extranjeros.

Argentina no ha adoptado el principio del forum non conveniens, por lo que los tribunales argentinos entenderán en la cuestión si se ha pactado así, aunque existiera otra jurisdicción más adecuada para tramitar la causa. No existe ningún antecedente jurisprudencial favorable al forum non conveniens y tampoco la doctrina ha propiciado la recepción del principio.

\section{b) Jurisdicción internacional en ausencia de elección}

En ausencia de acuerdo de las partes, los arts. 1215 y 1216 del Código Civil atribuyen jurisdicción en forma concurrente y a elección del actor, a los jueces del lugar de cumplimiento del contrato o a los del domicilio del demandado.

La doctrina argentina ha sostenido distintas interpretaciones sobre lo que se entiende por lugar de cumplimiento, a los fines de la determinación de la jurisdicción internacional.

Goldschmidt considera que para determinar la jurisdicción internacional debe considerarse el lugar de cumplimiento de la prestación reclamada en el juicio. ${ }^{24}$ Boggiano entiende que puede demandarse ante los jueces del lugar de cumplimiento de cualquiera de las prestaciones, postura que comparte Uzal. ${ }^{25}$

Este último criterio fue receptado en el fallo de la Cámara Nacional en lo Comercial, sala E, del 10 de octubre de 1985 en la causa "Espósito e Hijos S.R.L. c/ Jocqueviel de Vieu". ${ }^{26}$ Varias sentencias posteriotes de la Cámara Nacional en lo Comercial de la ciudad de Buenos Aires, han adoptado la misma solución. ${ }^{27}$

En materia de seguro marítimo el art. 620 de la ley de navegación 20.094, atribuye jurisdicción a los jueces argentinos cuando el domicilio del asegurador o en su caso, los de sus sucursales o agencias, están en Argentina. El asegurador tiene opción de litigar también ante los tribunales del domicilio del asegurado. Consideramos que la norma es inaplicable al reaseguro marítimo, aunque coincide sustancialmente con los criterios atributivos de los arts. 1215 y 1216 del Código Civil.

\footnotetext{
${ }^{24}$ GOLDSCHMIDT, ob. cit., parág. 315, pág. 396.

${ }^{25}$ BOGGIANO, Antonio Derecho Internacional Privado, $3^{\mathrm{a}}$. ed., Buenos Aires, Abeledo-Perrot, 1991, tomo I, pág. 253; UZAL, op. cit. págs. 20-22.

${ }^{26}$ Revista La Ley, Buenos Aires, tomo 1986-D, págs. 46-49 y Revista El Derecho, Buenos Aires, tomo 121, pág. 671. Ver: WEINBERG de ROCA, Inés Mónica Competencia internacional y ejecución de sentencias extranjeras, Buenos Aires, Astrea, 1994, parág. 12, págs. 28-29, quien parece no compartir el criterio del fallo Espósito.

${ }_{27}$ Cám. Nac. Com., sala C, 15 de marzo de 1991 "Quilmes Combustibles o/ Vigan S.A. s/ ord."; Cám. Nac. Com., sala A, 3 de abril de 1991 "Consolidated Bank N.A. c/ Heller, Bernardo s/ ord."; Cám. Nac. Com., sala A, 30 de mayo de 1991 "Franco Hnos. S.A. c/ Prescon s/ ord.", en todos los casos, se siguieron los dictámenes del Fiscal de Cámara. Los fallos están citados por UZAL, op. cit,, pág. 22, nota 23.
} 


\section{III. - JURISDICCION INTERNACIONAL ARBITRAL}

\section{1.- Tratados internacionales}

Argentina reconoce la validez de los acuerdos arbitrales incluso a favor de árbitros que actúen fuera del país, en asuntos internacionales de naturaleza patrimonial. En los últimos años ha ratificado convenciones sobre arbitraje y contiene también una regulación de fuente interna sobre el reconocimiento de laudos extranjeros, lo que garantiza que se reconocerá la validez de los acuerdos arbitrales y eventualmente la ejecución de los laudos.

La Convención Interamericana sobre Arbitraje Comercial Intemacional, suscripta en Panamá el 30 de enero de $1975^{26}$, en el marco de la Primera Conferencia Especializada sobre Derecho Internacional Privado, CIDIP - I. ${ }^{29}$, está vigente en Argentina desde 1995.

Argentina ratificó recién en 1989 la Convención sobre el Reconocimiento y la Ejecución de las Sentencias Arbitrales Extranjeras, suscripta en Nueva York el 10 de junio de $1958 .{ }^{30}$

La validez del acuerdo arbitral se rige, de acuerdo a estas Convenciones, por la ley elegida por las partes y en su defecto, por la ley del estado donde se dictó el laudo arbitral, es decir la sede del tribunal arbitral (art. V, 1, a, de la Convención de Nueva York y art. 5. 1.a. de la Convención de Panamá).

Hemos sostenido que entre los países del Mercosur, la Convención de Panamá de 1975, debe complementarse o integrarse con el Protocolo de Cooperación y Asistencia Iurisdiccional en Materia Civil, Comercial, Laboral y Administrativa, suscripto en Las Leñas, el 27 de junio de $1992^{31}$, en lo que se refiere al trámite del reconocimiento de los

\footnotetext{
${ }^{28}$ La Convención Interamericana sobre Arbitraje Comercial Internacional fue aprobada por Argentina por ley 24.322, de 1994. El instrumento de ratificación fue depositado el 5 de enero de 1995. La Convención tiene 16 Estados Parte, al 10 de septiembre de 1998. Ver: SANTOS BELANDRO, Ruben Arbitraje comercial internacional, Montevideo, Fundación de Cultura Universitaria, 1988, págs. 159-213, 2ª . ed. México, Pereznieto Editores, 1997, págs. 157-228.

29 Las Conferencias Interamericanas sobre Derecho Internacional Privado se llevaron a cabo en Panamá, 1975 (CIDIP-I), Montevideo, 1979 (CIDIP-II), La Paz, 1984 (CIDIP-III), Montevideo, 1989 (CIDIP-IV) y México, D.F., 1994 (CIDIP-V) y han aprobado veintitrés convenciones. Argentina es parte en doce de ellas. Ver por todos: FERNÁNDEZ ARROYO, Diego P. La Codificación del Derecho Internacional Privado en América Latina, Madrid, Eurolex, Ed. Beramar, 1994.

${ }^{30}$ La Convención de Nueva York de 1958 fue aprobada por Argentina por ley 23.619 del 28 de septiembre de 1988; el depósito del instrumento de ratificación se efectuó el 14 de marzo de 1989. Al $1^{\circ}$ de septiembre de 1998 son parte en esta Convención 116 Estados, pero Brasil es el único país del Mercosur que no la han ratificado aún. Ver: GRIGERA NAON, Horacio A. "Ratificación por la Argentina de la Convención de Nueva York de 1958 sobre reconocimiento y ejecución de laudos arbitrales extranjeros", en Revista La Ley, Buenos Aires, 1989-C, págs. 881-894; SANTOS BELANDRO, $o b$. cit., págs 3-137.

${ }^{31}$ El Protocolo de Las Leñas fue adoptado por decisión del Consejo Mercado Común (CMC) 5/92. Argentina lo aprobó por ley 24.578 del 25 de octubre de 1995. Ha sido ratificado por Argentina, Brasil y Paraguay. Sobre el Protocolo de Las Leñas ver: TELLECHEA BERGMAN, Eduardo "Panorama de los Protocolos del Mercosur sobre Derecho Internacional Privado, con especial referencia a aquellos relativos a la cooperación jurídica internacional", en Del Mercosur. Aduana. Jurisdicción. Informática. Relaciones Intercomunitarias., Buenos Aires, ed. Ciudad Argentina, 1996, págs. 187-241; ARGERICH, Guillermo "Eficacia extraterritorial de las sentencias extranjeras en los procesos de integración (Análisis comparativo de las regulaciones del Mercosur y de la Comunidad Europea)", en Revista Jurisprudencia Argentina, Buenos Aires, 1997-111-págs. 833-839; DREYZIN de Klor, Adriana El Mercosur. Generador de una nueva fuente de derecho internacional privado, Buenos Aires, Zavalía, 1997, págs. 261-281.
} 
laudos. ${ }^{32}$

El Mercosur ha aprobado el Acuerdo sobre Arbitraje Comercial Intemacional del Mercosur (CMC/DEC No 3/98) y el Acuerdo sobre Arbitraje Comercial Internacional entre el Mercosur, la República de Bolivia y la República de Chile (CMC/DEC № 4/98), ambos firmados en Buenos Aires, el 23 de julio de 1998.

Los Acuerdos del Mercosur regulan básicamente: el acuerdo arbitral (arts. 4 -8) el procedimiento arbitral (arts. $11-25$ ), que incluye el laudo arbitral y los recursos contra el mismo (arts. 20-22) y el derecho aplicable por los átbitros al fondo del litigio (arts. 9 y 10). Deliberadamente, los Acuerdos del Mercosur no contienen normas sobre reconocimiento y ejecución de los laudos (art. 23).

Cuando entren en vigencia, resultarán aplicables a los acuerdos arbitrales en contratos de reaseguros, no sólo entre particulares con residencia habitual o establecimiento en estados del Mercosur, sino también con relación a personas de terceros Estados, ya que el ámbito de aplicación espacial de los Acuerdos es considerablemente amplio (art. 3).

\section{2.- Sistema de fuente interna argentino}

El art. 1 del Código Procesal Civil y Comercial de la Nación, ya comentado, permite además de los pactos de jurisdicción, los acuerdos arbitrales incluso a favor de árbitros que actúen fuera de Argentina, siempre que el contrato sea internacional. El art. 519 bis del mismo Código contempla las condiciones en las cuales se ejecutan los laudos extranjeros.

Entre las circunstancias que invalidan el acuerdo arbitral y obstan a la ejecución del laudo, se encuentra que la materia no sea susceptible de ser sometida a arbitraje, conforme el art. 737 del mismo Código (art. 519 bis inc. $2^{\circ}$ ). Se trata de las cuestiones que no pueden ser objeto de transacción.

Señala Horacio Grigera Naón que "según el derecho argentino, cualquier materia que pueda ser objeto de transacción por las partes - sea esta de naturaleza comercial, civil o administrativa o de cualquier otra naturaleza - puede ser sometida a arbitraje. Esto se interpreta normalmente como excluyendo del arbitraje toda materia de naturaleza no patrimonial referente al estatuto personal, derecho de familia, sucesiones, tutela, curatela y filiación". ${ }^{33}$

Sin embargo, hay cuestiones comerciales que no son arbitrables, por ejemplo en materia de derecho marítimo (art. 614 de la ley 20.094 de navegación). Sostiene Grigera Naón que no parecería que los árbitros puedan decidir en la Argentina cuestiones vinculadas con la validez de patentes o marcas o en materia de defensa de la competencia, en la medida en que no se trate de disputas que no conciernan exclusivamente reclamos

\footnotetext{
${ }^{32}$ NOODT TAQUELA, María Blanca "Arbitraje internacional entre particulares en el Mercosur", en Revista Jurisprudencia Argentina, Buenos Aires, tomo 1996-Ill, págs. 710-718.

${ }^{33}$ GRIGERA NAON, Horacio A. "La ley modelo sobre arbitraje comercial internacional y el derecho argentino", en Revista La Ley, Buenos Aires, tomo 1989-A, págs. 1021-1051, espec. pág. 1025.
} 
de naturaleza patrimonial entre partes privadas respecto de dichas cuestiones. ${ }^{34}$

El art. 57 de la ley $17.418^{35}$, que prohibe las cláusulas compromisorias en la póliza de seguro, no se considera aplicable al reaseguro, ya que "siendo la prohibición de las cláusulas compromisorias en el contrato de seguros una norma restrictiva de derechos, no cabe su interpretación extensiva a otros contratos como el de reaseguro". ${ }^{36}$

IV.- AUTONOMIA DE LA VOLUNTAD. ELECCION DE LA LEY APLICABLE ALCONTRATO DE REASEGURO

\section{1.- Convención interamericana , México 1994. Posibilidad de aplicación en el Mercosur}

La Quinta Conferencia Interamericana de Derecho Internacional Privado, realizada en México del 14 al 18 de marzo de 1994, aprobó la Convención Interamericana sobre Derecho Aplicable a los Contratos Internacionales, el 17 de marzo de $1994 .{ }^{37} \mathrm{La}$ Convención ha sido ratificada solo por México y Venezuela hasta el momento, pero su adopción por los países del Mercosur podría constituir un primer paso para la regulación de los contratos internacionales en la región.

La CIDIP.V acepta la autonomía de la voluntad en su forma más amplia (arts. 7 y 8). No se exige contacto alguno entre la ley elegida y el contrato; la voluntad puede manifestarse en forma expresa o "desprenderse en forma evidente de la conducta de las partes y de las cláusulas contractuales, consideradas en su conjunto" (art. 7.1) Es interesante señalar

\footnotetext{
34 GRIGERA NAON, "La ley modelo...", op. cit., pág. 1028.

${ }^{35} \mathrm{El}$ art. 57 de la ley 17.418 dice: Son nulas las cláusulas compromisorias incluidas en la póliza. La valuación del daño puede someterse a juicio de peritos.

${ }^{36}$ MORANDI y otros "Modificación....", op. cit., pág. 175; en el mismo sentido FRANCO TORTORA, Silvia Beatriz "Arbitraje: Procedencia legal, funcionamiento y revisión judicial", en Revista Mercado Asegurador, Buenos Aires, vol. 192, mayo de 1995, págs. 32-33.

${ }^{37}$ Existe ya una extensa bibliografía sobre esta Convención Ver, entre otros: HERBERT, Ronald "La Convención Interamericana sobre Derecho Aplicable a los Contratos Internacionales" en Revista Uruguaya de Derecho Internacional Privado, Montevideo, 1994, año 1, no 1, p. 45-62; FERNÁNDEZ ARROYO, Diego P. "La Convention interaméricaine sur la lol applicable aux contrats internationaux: certains chemins conduisent au-delà de Rome» en Revue critique de droit international privé, Paris, vol. 84, 1995-1, págs. 178-186; JUENGER, Friedrich K. "The Inter-American Convention on the Law Applicable to International Contracts: Some Highlights and Comparisons" en The American Journal of Comparative Law, Vol. XLII, Spring 1994, $n^{\circ} 2$, págs. 381-393; ARAUJO, Nadia de Contratos internacionais, Río de Janeiro, Renovar, 1997, págs. 157-184; FRESNEDO de AGUIRRE, Cecilia "La Convención interamericana sobre derecho aplicable a los contratos internacionales, aprobada en la Quinta Conferencia Especializada Interamericana sobre Derecho Internacional Privado (CIDIP - V) - México-1994" en Anuario de Derecho Comercial, Montevideo, tomo 7, 1996, págs. 191-211; NOODT TAQUELA, María Blanca "Convención Interamericana sobre el Derecho Aplicable a los Contratos Internacionales", en Revista del Derecho Comercial y de las Obligaciones, Buenos Aires, Depalma, 1996, págs. 397. 434; y en El Derecho internacional privado interamericano en el umbral del siglo XXI. Sextas Jornadas de Profesores de Derecho internacional privado. Segovia, 1 y 2 de diciembre de 1995, Madrid, Universidad Complutense de Madrid, Eurolex, 1997, págs. 89-134.
} 
que la Convención ha entendido que "La selección de un determinado foro por las partes no entraña necesariamente la elección del derecho aplicable" (art. 7.2).

Se permite también el fraccionamiento de la ley aplicable - depéçage - , es decir la elección de distintas leyes para regir distintas partes del contrato (art. 7.1) y la modificación del derecho elegido, sin afectar la validez formal del contrato ni los derechos de terceros (art. 8).

Para que pueda elegirse la ley aplicable al contrato, la Convención de México exige que su internacionalidad quede evidenciada por elementos objetivos (art.1), aspecto en el que resulta más exigente que la Convención de Roma de 1980 (art. 3.3).

La libertad de las partes tendrá el límite de los principios de orden público internacional (art. 18) y de las normas de policía del foro y de terceros estados suficientemente vinculados con el contrato (art. 11).

Hay que destacar que la Convención Interamericana no tiene carácter universal, a pesar de que su art. 2, similar al art. 2 de la Convención de Roma de 1980, podría llevar a considerarla erga omnes, como lo han sostenido algunos autores ${ }^{38}$. El art. 1 exige para determinar la internacionalidad del contrato y por ende el ámbito de aplicación de la Convención, que el contrato tenga contactos objetivos con más de un Estado Parte. Si bien el contrato puede regirse por la ley de un Estado no Parte (art. 2), la aplicación de la Convención exige contactos objetivos con dos Estados Parte (art.1), lo que le quita el carácter universal. ${ }^{39}$

Los contratos de reaseguro deben considerarse comprendidos en el ámbito de aplicación de la Convención, ya que no figuran entre los excluidos del art.5, ni tienen una regulación autónoma en el derecho convencional internacional vigente entre los Estados Partes de la Convención, lo que determinaría su exclusión según el art. 6.

Cecilia Fresnedo de Aguirre ha analizado detenidamente la inaplicabilidad de la Convención a los contratos de transporte y de seguro, pero no se ha teferido a los de reaseguro. ${ }^{40}$ Consideramos que la existencia de un poder negociador relativamente equivalente entre las partes, la circunstancia de no tratarse de contratos por adhesión y el hecho de que ambas partes sean profesionales, razones que ya hemos expuesto, hacen aplicable la Convención de México al reaseguro, al igual que sucede con la Convención de Roma (art. 1.3 y 1.4), pues no concurren los motivos que justifican no aplicarla en materia de seguros.

\footnotetext{
${ }^{38}$ FERNANDEZ ARROYO, Diego P. op. cit, Revue critique, págs. 181-182.

${ }^{39}$ NOODT TAQUELA, María Blanca "Convención ...", op. cit., Buenos Aires, págs. 426-429 y Madrid, págs. 126-129. En sentido similar: OPERTTI BADÁN, Didier "La CIDIP V: una visión en perspectivam en Revista Uruguaya de Derecho Internacional Privado, Montevideo, 1994, año 1 , $n^{0} 1$, p. 13-43, esp. págs. 27-28.

${ }^{40}$ FRESNEDO de AGUIRRE, Cecilia "Los contratos de transporte y de seguros frente a la Convención interamericana sobre derecho aplicable a los contratos internacionales" en Revista de Transporte y Seguros, Montevideo, Comisión Local de Aseguradores, $n^{\circ}$ 8, agosto de 1995, págs. 157-176.
} 
La importancia que la Convención reviste para todos los países americanos se incrementa entre los que componen el Mercosur, ya que los sistemas de Derecho Internacional Privado de fuente interna de estos países, con excepción de Argentina, rechazan la autonomía de la voluntad, ya sea a través de una norma expresa, como en el caso de Uruguay (art. 2403 del Apéndice del Código Civil, ley 10.084) ${ }^{41}$ o porque carecen de una norma que la permita.

Por otra parte, Argentina, Paraguay y Uruguay están vinculados por los Tratados de Montevideo de 1940, cuyo Protocolo Adicional, prohibe la elección de la ley aplicable al contrato (art. V).

La ratificación o aprobación de esta Convención, por parte de los Estados Miembros del Mercosur, permitiría contar con una regulación mínima de los contratos internacionales en la región. ${ }^{42}$

\section{2.- Tratados de Montevideo de 1940}

Los Tratados de Derecho Civil Intemacional y de Derecho Comercial Terrestre Internacional, de Montevideo de 1940 han sido ratificados por Argentina, Paraguay y Uruguay. Corresponde entonces aplicarlos a los contratos de reaseguro entre partes domiciliadas en esos países.

Los Tratados de Montevideo de 1940 rechazan en forma expresa la autonomía de la voluntad. El art. V del Protocolo Adicional a los Tratados dispone: La jurisdicción y la ley aplicable según los respectivos Tratados, no pueden ser modificadas por voluntad de las partes, salvo en la medida en que lo autorice dicha ley.

La norma ha sido interpretada en el sentido de que si el derecho internacional privado de fuente interna del país cuya ley resultaría aplicable al contrato internacional, acepta la autonomía de la voluntad, es válida la elección de otro derecho efectuada por las partes. Se postula así una suerte de reenvío de las normas convencionales a las de fuente interna. Así lo han sostenido en Argentina Werner Goldschmidt y Antonio Boggiano y varios autores uruguayos. ${ }^{43}$

De acuerdo a esta interpretación, si un contrato internacional celebrado entre una empresa uruguaya y otra argentina, tiene lugar de cumplimiento en Argentina, la cláusula de elección del derecho uruguayo o de un tercer país, sería válida, pues de acuerdo a los arts. 37 y 38 del Tratado de Derecho Civil Intemacional de Montevideo de 1940, los contratos se rigen por la ley del lugar de cumplimiento, que en el caso es Argentina y el derecho internacional privado argentino de fuente interna acepta la autonomía de la voluntad.

\footnotetext{
${ }^{41}$ FRESNEDO de AGUIRRE, Cecilia La autonomia de la voluntad...., op. cit, págs. 67-73. ${ }^{42}$ NOODT TAQUELA, María Blanca "Contratos internacionales en el Mercosur. Conveniencia de adoptar la Convención interamericana sobre derecho aplicable a los contratos internacionales, CIDIP.V", en Revista Doctrina Judicial La Ley, Buenos Aires, tomo 1996- II, págs. 929-931.

${ }^{43}$ FRESNEDO de AGUIRRE La autonomía de la voluntad ...op. cit., págs. 65-73.
} 


\section{3.- Tratados de Montevideo de 1889}

Los Tratados de Montevideo de 1889 no contienen norma que prohiba o que permita la autonomía de la voluntad conflictual. El silencio del Tratado ha dado lugar a interpretaciones diferentes.

Para la doctrina uruguaya mayoritaria, los Tratados de 1889 no autorizan la elección de la ley aplicable al contrato.

Para la doctrina argentina mayoritaria, el silencio de los Tratados debe ser interpretado en el sentido de que se autoriza la autonomía, en virtud del principio constitucional de reserva (art. 19 de la Constitución Argentina).

\section{El sistema de fuente interna argentino}

No existe una norma expresa en el Derecho Internacional Privado argentino de fuente interna que recepte la autonomía de la voluntad conflictual.

La doctrina iusprivatista argentina mayoritaria considera desde hace varias décadas que las partes pueden elegir el derecho aplicable a los contratos internacionales, postura pacífica actualmente.

Las XJomadas Nacionales de Derecho Civil, reunidas en Corrientes en 1985, aceptaron en forma unánime la autonomía de la voluntad como punto de conexión en los contratos internacionales. ${ }^{44}$

Los autores han utilizado distintos fundamentos para sostener la autonomía de la voluntad conflictual. ${ }^{45}$ Quizás el más interesante es el expuesto por Boggiano ${ }^{46}$, que se basa en la norma que autoriza los acuerdos de elección de foro en contratos internacionales (art. 1 del Código Procesal Civl y Comercial de la Nación, aprobado por ley 17.454, modificado por ley 21.305 de 1976 y actualmente por ley 22.434 de 1981).

El razonamiento es el siguiente: Según el art. 1 del Código Procesal Civily Comercial de la Nación, las partes pueden elegir el tribunal competente. Luego, las partes pueden elegir el Derecho Internacional Privado del país al que pertenezca el tribunal elegido pues cada juez aplica su propio sistema de Derecho Internacional Privado. Si las partes pueden elegir el Derecho Internacional Privado que rige el contrato, pueden también elegir el derecho privado aplicable, ya que este se determina según el Derecho Internacional Privado elegido. Pudiendo ser elegido el Derecho Internacional Privado, que es lo más, se puede elegir el derecho aplicable, que es lo menos. ${ }^{47}$

\footnotetext{
$\overline{44}$ El Derecho Privado en la Argentina. Conclusiones de Congresos y Jornadas de los últimos treinta años, Buenos Aires, Universidad Notarial Argentina, 1991, pág. 49.

${ }^{45}$ GOLDSCHMIDT, op. cit., $\mathrm{n}^{\circ}$ 182-183, págs. 198-202.

${ }^{46}$ BOGGIANO, op. cit., t. II, pág. 256.

${ }^{47}$ BOGGIANO, op. cit., t. II, págs. 257-259.
} 
La jurisprudencia argentina ha aceptado también la elección de la ley en contratos internacionales, salvo en materia de derecho marítimo, ámbito en el cual es rechazada sistemáticamente. ${ }^{48}$

No he encontrado casos que desconozcan en forma expresa la autonomía de la voluntad, pero no creo que todavía pueda decirse que el principio esté incorporado totalmente en la conciencia jurídica judicial. La jurisprudencia de Derecho Internacional Privado no es muy abundante, en parte porque muchos casos internacionales son tratados, pienso que inadvertidamente, como casos internos. Por otra parte, es habitual que se recurra al arbitraje, o que los conflictos se solucionen sin acudir a una jurisdicción estatal o arbitral.

De cualquier modo, la jurisprudencia argentina registra una considerable cantidad de pronunciamientos judiciales que receptan la autonomía de la voluntad en Derecho Internacional Privado. ${ }^{49}$

Específicamente en materia de reaseguros, algunos autores especialistas en seguros defienden la autonomía de la voluntad. Hector A. Perucchi sostuvo en las V Jomadas Nacionales de Derecho de Seguros, que las partes pueden libremente elegir la ley aplicable al contrato de reaseguro..$^{50}$

Sin embargo, al elaborarse el Anteproyecto de 1993 sobre modificación del título II de la ley 17.418, que regula el reaseguro, la mayoría de los especialistas en Derecho de Seguros, sostuvieron un criterio diferente.

\footnotetext{
${ }^{40}$ Caso "Compte c/ Ybarra y Cla" cit. en nota 20.

${ }^{49}$ Corte Suprema de Justicia, 10 de diclembre de 1956 "Gobierno del Perú c/ Sifar Soc. Ind. Financ. Argentina” en Fallos t. 236, pág. 404 y en Revista La Ley, Buenos Aires, t. 86, pág. 329; Cám. Nac. Com., sala C, 15 de septiembre de 1960 «Glatz, Friedrich c/Plata Americana S.R.L. y otros" en Revista El Derecho, Buenos Aires, t. 1, pág. 15; Juzg. Nac. Paz o 46, firme 7 de octubre de 1969 "Estudios Espíndola c/ Bollati, Cristobal J." en Revista El Derecho, Buenos Aires, t. 33, pág. 26, en Revista Jurisprudencia Argentina, Buenos Aires, 1970, t. 8, pág. 1; Trib. del Trabajo de Zárate (Pcia. de Buenos Aires), 9 de diciembre de 1970, "Eiras Pérez, Leonardo c/Techint Engineering Company S.A." en Revista La Ley, Buenos Aires, t. 142, pág. 176; Corte Suprema de Justicia, 28 de abril de 1971 "A.J. Hollander Arg. S.A. c/ Banco Central de la República Argentina” en Revista Jurisprudencia Argentina, Buenos Aires, 1972, 1. 14, pág. 420; Juzg. Nac. Com. no 13, firme, 31 de agosto de 1976 «Pablo Treviso S.A.F.A.C.I.M.I. y otros c/ Banco Argentino de Comercio" en Revista El Derecho, Buenos Aires, t. 77, pág. 426 y en BOGGIANO, op. cit., t. II, págs, 471-488; Cám. Nac. Fed., sala I, cont. adm., 2 de octubre de 1979 "Saier S.R.L. c/ Comisión Técnica Mixta de Salto Grande", especialmente el dictamen del Procurador de Cámara, en Revista La Ley, Buenos Aires, t. 1979-D, pág. 488; Cám. Nac. Com., sala E, 20 de octubre de 1981 "Banco de Río Negro y Neuquén c/ Independencia Transportes Internacionales S.A." en Revista El Derecho, t. 97, pág. 604; Corte Suprema de Justicia, 15 de marzo de 1994, "Tactician Int. Corp. y otros c/ Dirección General de Fabricaciones Militares s/ cumplimiento de contrato", en Revista La Ley, Buenos Aires, 1995-C, págs. 128-133. 50 PERUCCHI, Héctor A. "Derecho de Reaseguros ( $1^{2}$ nota)", en Gaceta del Seguro, Buenos Aires, $n^{\circ}$ 1, febrero de 1994, págs. 5-8, espec. pág. 7. En el mismo sentido FRANCO TORTORA, Silvia Beatriz "Legislación del contrato de reaseguro. Modificación al título ll de la ley 17.418. Crítica del proyecto. Presentación del anteproyecto de reforma", en I Jornadas sobre Política de Legislación de Seguros y Reaseguros, realizadas en la Cámara de Diputados de la Nación, en noviembre de 1994. Buenos Aires, 1995, págs. 148-171.
} 
El proyectado art. 160, primer párrafo, que no ha tenido sanción legislativa, no autorizaba a las partes a elegir la ley aplicable, ya que disponía: "En los contratos de reaseguro en que sea parte un asegurador cedente autorizado a operar en el país, la ley aplicable será la argentina".

En cambio, en los contratos de retrocesión, el proyectado art. 160, segundo párrafo establecía: "En los casos de retrocesiones en las que sea parte un retrocedente radicado en el exterior, se podrá elegir la ley aplicable, que en caso de ser extranjera, tendrá que sujetarse a los dispuesto por el art. 14 del Código Civil".

\section{5.- Autonomía de la voluntad material. Usos del comercio internacional}

La escasa regulación legal del contrato de reaseguro, tanto en Argentina, como en los demás países del mundo, favorece el ejercicio de la autonomía de la voluntad de las partes, ya que las cláusulas contractuales sólo tendrá como límites, además de las normas de aplicación inmediata, los principios de orden público internacional.

Puede ser interesante para las partes convenir la aplicación de los Principios aplicables a los contratos internacionales, elaborados por UNIDROIT ${ }^{\text {s1 }}$, para regir su contrato, sin perjuicio claro está, de las cláusulas especiales que adopten en razón del tipo contractual, es decir las específicas sobre reaseguros.

Los Principios de UNIDROIT, pueden significar una herramienta muy útil en la contratación internacional. Sus reglas no se verán alteradas por las normas internas del derecho que resulte aplicable al contrato internacional, salvo cuando se trate de normas de aplicación inmediata (art. 1.4).

En cuanto a los usos del comercio internacional, se ha señalado la dificultad existente en Argentina y otros países que han tenido durante muchos años un monopolio estatal en materia de reaseguros, para aplicar los usos en materia de reaseguros. El desconocimiento y la inexperiencia de los aseguradores argentinos, por tantos años de inactividad en el tema, pueden llevar a una utilización indebida de esta fuente. Peruchi. afirma que los usos internacionales requieren para su aplicación los siguientes requisitos: a) que se trate de un uso de aplicación universal y no solamente en el país reasegurador o en países sometidos a regímenes jurídicos similares; b) que tal aplicación universal sea dictaminada por un pronunciamiento pericial; c) que el uso o costumbre a aplicar no sea contrario a una norma de orden público del ordenamiento jurídico aplicable. ${ }^{52}$

Por otra parte, en cuanto a los aspectos generales del contrato, los Principios aplicables a los contratos internacionales, elaborados por UNIDROIT, se convertirán probablemente en usos del comercio in ternacional, que serán aplicados por jueces y árbitros.

51 UNIDROIT, Principios sobre los contratos comerciales internacionales, Roma, UNIDROIT, 1995. 52 PERUCCHI, op. cit., pág. 7. 


\section{6.- Límites a la autonomía de la voluntad}

La autonomía de la voluntad tiene como presupuesto la internacionalidad del contrato y como límites el fraude a la ley, el orden público internacional y las normas de policía del foro y extranjeras.

La doctrina argentina exige en forma unánime la internacionalidad del contrato, para permitir la elección de una ley extranjera. ${ }^{53} \mathrm{El}$ mismo criterio impera en los demás países del Mercosur, e incluso en el resto de Latinoamérica, como quedó muy claro en la conferencia de CIDIP.IV, al aprobarse las Bases para la futura Convención sobre Derecho aplicable a los Contratos Intemacionales, cuyo art. 1 exigía la presencia de elementos objetivos localizados en Estados diversos para que se configurara la internacionalidad del contrato, exigencia que fue mantenida por la CIDIP-V sobre Contratos (art. 1).

En cuanto a los elementos que determinan la internacionalidad del contrato, Boggiano afirma que "un contrato es internacional tanto si su celebración se vincula a varios sistemas jurídicos por los domicilios de oferentes y aceptantes, como si su ejecución es multinacional". ${ }^{54}$

En nuestra opinión la calificación debe ser amplia, de modo de considerar internacional el contrato que tenga algún elemento objetivo extranjero ${ }^{55}$, tal como lo hace la Convención de México.

La nacionalidad extranjera de una o ambas partes no será considerada seguramente por un juez argentino como un elemento objetivo que internacionaliza el contrato, ya que no se trata de una conexión relevante para el Derecho Internacional Privado argentino.

El fraude a la ley, entendido como impedimento para la aplicación del derecho indicado por el punto de conexión, que queda desplazado, en favor de la ley que las partes quisieron eludir, puede constituir otro límite a la autonomía de la voluntad de las partes.

El fraude no cabe cuando el legislador permite libremente a las partes elegir el derecho aplicable, pero como acertadamente lo señala Boggiano, cuando las partes pretenden evadir las normas coactivas del derecho normalmente competente, crean artificialmente elementos extranjeros que conducirían al juez a la aplicación de un derecho extranjero. ${ }^{56}$

El Derecho Internacional Privado argentino, en lo que se refiere a contratos internacionales, sanciona tanto el fraude a la ley del juez como a la ley extranjera (arts. 1207 y 1208 del Código Civil), criterio que es compartido por la mayoría de los autores. ${ }^{57}$

$\mathrm{El}$ art. 6 de la Convención Interamericana sobre Normas Generales de Derecho Internacional Privado, suscripta en Montevideo el 8 de mayo de 1979- CIDIP-II -, aprobada

\footnotetext{
${ }^{53}$ BOGGIANO, op. cit., tomo II, págs. 258-259; GOLDSCHMIDT, op. cit, parág 315, pág. 393. 54 BOGGIANO, op. cit., tomo Il, págs. 258-259. Ver la calificación de GOLDSCHMIDT, op. cit., parág 315, pág. 393.

${ }^{55}$ BOGGIANO, op. cit., tomo I, pág. 484.

${ }^{58}$ BOGGIANO, op. cit, tomo I, págs. 482 y 484.

${ }^{57}$ GOLDSCHMIDT, op. cit, parág. 128, págs. 116-117; BOGGIANO, op. cit., tomo 1, pág. 485-486. En contra: PARDO, Juan Alberto Derecho Internacional Privado. Parte General, Buenos Aires, Abaco, 1976, pág. 352.
} 
por Argentina por ley 22.921 de 1983, puede considerarse aplicable tanto en la esfera convencional, como en el ámbito interno, ya que se ha entendido que la Convención tiene carácter universal. ${ }^{58}$

La libertad de las partes en la contratación internacional tendrá siempre el límite de los principios de orden público internacional del derecho del juez, límite que el Derecho Internacional Privado impone a la aplicación del derecho extranjero en general y al reconocimiento de sentencias y laudos extranjeros. Tanto la Convención Interamericana sobre Normas Generales de Derecho Intemacional Privado (art. 5), como el art. 14 inc. $2^{\circ}$ del Código Civil, conciben el orden público como conjunto de principios y la Convención destaca, además, su carácter excepcional.

Las normas de policía o normas de aplicación inmediata o normas imperativas constituyen otro límite o exclusión de la autonomía de la voluntad de las partes, reconocido por el Derecho Internacional Privado argentino, aunque no exista una norma general en el sistema de fuente interna.

Boggiano afirma que frente a las normas de polićá, la autonomía de las partes no resulta limitada, sino excluida en los aspectos regulados por dichas normas. ${ }^{59}$

Argentina ha ratificado algunas Convenciones de La Haya, que contemplan las normas de policía del juez o las normas de policía del juez y de terceros estados. ${ }^{60}$

La jurisprudencia de los tribunales argentinos aplica las normas de policía argentinas y en algunas oportunidades ha tomado en consideración normas de aplicación inmediata extranjeras. Una antigua sentencia de 1944 aplica normas de policía uruguayas, que prohibían la exportación e impedían el embarque de la mercadería que debía efectuarse en Montevideo. ${ }^{61}$

${ }^{58}$ GOLDSCHMIDT, Werner "El derecho extranjero en el proceso", en Revista El Derecho, Buenos Aires, tomo 115, 1985, págs. 802-804; FERME, Eduardo L. "Convención Interamericana sobre Normas Generales", en Enciclopedia Jurídica Omeba, Buenos Aires, Apéndice V, 1987, págs. 209-217, espec. págs. 210 - 211.

${ }^{59}$ BOGGIANO, op. cit, tomo II, págs. $259-260$ y 266; también tomo I, págs. 515-528.

* Convención de La Haya de 1986 sobre la ley aplicable a los contratos de compraventa internacional de mercaderias (art. 17), aprobada por Argentina por ley 23.916 de 1991, que no ha entrado en vigencia; Convención de La Haya de 1978 sobre la ley aplicable a los contratos de intermediarios y a la representación (art. 16), aprobada por Argentina por ley 23.964 de 1991 vigente desde el $1^{2}$ de mayo de 1992, entre Argentina, Francia, Países Bajos y Portugal. Ver: NOODT TAQUELA, María Blanca "Compraventa internacional de mercaderías", en Enciclopedia Jurídica Omeba, apéndice VII, Buenos Aires, 1996, págs.161-195, las normas de policía están tratadas en págs. 182-185; NAJURIETA, Maria Susana "Compraventa internacional. Aportes de la Convención de La Haya de octubre de 1985", en Revista del Derecho Comercial y de las Obligaciones, Buenos Aires, Depalma, 1988, año 21, págs. 67-91; BOGGIANO, Antonio Contratos internacionales, $2^{\mathrm{a}}$. ed., Buenos Aires, Depalma, 1995, págs. 35-76.

${ }^{61}$ Cámara Comercial de la Capital Federal, Argentina, 9 de junio de 1944 "Goja, Humberto c/ Livio C. Costa", en Revista Gaceta del Foro, Buenos Aires, tomo 170, págs. 468-470. 


\section{V. - LEY APLICABLE EN AUSENCIA ELECCION}

\section{1.- Convención Interamericana, México, 1994}

Como principio general subsidiario, en ausencia de elección de las partes, la Convención de México de 1994, tal como lo dispone el Convenio de Roma de 1980 (art. 4.1.), establece que el contrato se rige por el derecho del Estado con el cual tenga los vínculos más estrechos (art, 9.1). Se ha adoptado el sistema de conexión flexible, por primera vez en la esfera interamericana.

La Convención no establece presunciones ni da ningún criterio orientador para determinar el derecho aplicable. Solamente indica que el tribunal tomará en cuenta todos los elementos objetivos y subjetivos que se desprendan del contrato para determinar el derecho del Estado con el cual tiene vínculos más estrechos. La prestación característica no aparece en la Convención de CIDIPV, ni como criterio para determinar la ley aplicable al contrato, ni como presunción de conexión más estrecha, eliminación que considero desafortunada, pues se trata de un criterio que goza de suficiente aceptación en la doctrina y en la jurisprudencia de la gran mayoría de los países y que hasta ahora no ha sido suplantado por otro mejor. ${ }^{62}$

A pesar de la supresión, no me cabe ninguna duda de que la prestación característica ha de utilizarse al aplicar la Convención. Al quedar abierta a la decisión judicial la determinación de la ley aplicable en ausencia de elección por las partes, se permite que el juez utilice el criterio que le parezca más apropiado y lo cierto es que en materia de contratos internacionales, si se dejan de lado los puntos de conexión rígidos, no se han difundido otros criterios que permitan dejar de lado la prestación característica.

Es lamentable la omisión, pues la teoría de la prestación característica es entendida a veces como referida al lugar donde físicamente se cumple esa prestación y otras como aludiendo al domicilio, a la residencia habitual o al establecimiento de la parte deudora de la prestación característica. ${ }^{63}$

La Convención permite que el juez aplique más de una ley al contrato: «dépeçage legal» que se recepta con carácter excepcional, cuando una parte del contrato fuera separable del resto y tuviese una conexión más estrecha con otro Estado (art. 9.3).

\footnotetext{
62 En contra: F.K. Juenger, «The Inter-American Convention...», op. cit., pág.392, quien afirma que solamente por haber dejado de lado la antifuncional teoría de la prestación característica, la Convención de México es claramente superior al Convenio de Roma de 1980.

${ }^{63}$ DE MIGUEL ASENSIO, Pedro A. "La Ley aplicable en defecto de elección a los contratos internacionales: el art. 4 del Convenio de Roma de 1980», en Revista La Ley, Madrid, diario del 4 de abril de 1995, págs. 4-5. En Argentina han interpretado que la prestación característica indica la ley donde se cumple físicamente esa prestación: GOLDSCHMIDT, Derecho Internacional..., op. cit., $n^{0} 315$, p. 395; fallo del Juzgado Nacional de Paz $n^{0} 46$, del 7 de octubre de 1969, firme, "Estudios Espíndola c/Bollati, Cristobal J.» en Revista El Derecho, Buenos Aires, t. 33, p. 26. Por lo contrario, aluden al domicilio del deudor de la prestación característica: Boggiano Derecho Internacional Privado, ob. cit., t. II, págs. 620-623; NAJURIETA, María Susana "El domicilio del deudor de la prestación característica en los contratos multinacionales", en Revista Doctrina Judicial, La Ley, Buenos Aires, 1985-1, págs. 287- 293.
} 
La aplicación de la Convención de México al reaseguro no ha sido aún analizada por la numerosa doctrina ya existente sobre la Convención. Mucho menos puede encontrarse jurisprudencia que la aplique en materia de reaseguros, ya que solo rige entre México y Venezuela.

Pensamos que en el marco de la Convención de México resultan aplicables al reaseguro los análisis efectuados por la doctrina europea respecto de la Convención de Roma de 1980, no obstante la eliminación de la prestación característica de la Convención de México, por las razones que ya hemos expresado.

La prestación característica en el contrato de reaseguro es la obligación del reasegurador, del mismo modo que en el contrato de seguro la prestación del asegurador es la característica, es decir la obligación de cubrir el riesgo y no la de pagar la prima. ${ }^{64} \mathrm{Sin}$ embargo, en general no se considera que el contrato de reaseguro se rige por la ley del establecimiento del reasegurador, porque suele ser, como afirman Fernández Rozas y Sánchez Lorenzo, una conexión aislada, aleatoria y poco ope tativa ${ }^{65}$

Señalan los autores españoles que es "aislada porque no suele coincidir con el lugar de establecimiento del asegurador - reasegurado, ni con la localización del riesgo, ni con el mercado afectado por la operación, cuando estas tres conexiones pueden o suelen coincidir en un mismo Estado, distinto al del establecimiento de la entidad reaseguradora; aleatoria porque la actividad de reaseguro se centraliza, en su mayor parte, en grandes entidades con sede en ciertos Estados, como el Reino Unido o Suiza, cuya ley, resultaría, por tanto repetitivamente aplicable; poco operativa, porque en la mayoría de los casos el tiesgo se dispersa entre diferentes reaseguradores establecidos en distintos Estados, por lo que la coherencia final de la operación aconseja centrar el régimen conjunto de la ley aplicable en torno a la ley del establecimiento del asegurador-reasegurado" ${ }^{66}$

\footnotetext{
${ }^{64}$ FERNANDEZ ROZAS, José Carlos y SANCHEZ LORENZO, Sixto "Derecho Aplicable al Contrato de Reaseguro Internacional: Perspectiva española" en V Congreso Iberolatinoamericano de Derecho de Seguros. Madrid, 16 - 19 de septiembre de 1997, Madrid, Winterhur, 1997, tomo 1. págs.35-70, espec. pág. 52. En el mismo sentido: LE CORFF, Patrick "Derecho aplicable al Contrato de Reaseguro. Aproximación sobre el derecho internacional francés", en $V$ Congreso Iberolatinoamericano de Derecho de Seguros, ob. cit, págs.115- 164, espec. pág. 143; VAQUERO LOPEZ, María del Carmen "La cuestión de la determinación del derecho aplicable al contrato de Reaseguro en el ordenamiento jurídico español", en $V$ Congreso lberolatinoamericano de Derecho de Seguros, op. cit., págs. 71-94, espec, pág. 80; MORALES SEGURA, Cristina "Ley aplicable a los contratos de reaseguro", en Revista Española de Seguros, 1993, págs. 49-55, espec. pág. 51; CRESPO HERNANDEZ, Ana "Contrato de seguro" en FERNANDEZ ROZAS, José Carlos (editor) Derecho del Comercio Internacional, Madrid, Eurolex, 1996, págs. 369-380, espec. pág. 379 .
}

${ }^{65}$ FERNANDEZ ROZAS, y SANCHEZ LORENZO "Derecho Aplicable al Contrato de Reaseguro...", op. cit., pág. 52.

${ }^{66}$ FERNANDEZ ROZAS y SANCHEZ LORENZO, op. cit, págs. 52-53. En el mismo sentido: GERATHEWOHL, Klaus Reaseguro Teoria y práctica, vol. 1, Madrid, traducción de Teodoro Díez Arias, págs. 548-552; BLANCO-MORALES LIMONES, Pilar El seguro en Derecho internaciona! privado comunitario, Madrid, Caser, 1989, pág. 414, cit. por FERNANDEZ ROZAS y SANCHEZ LORENZO, op. cit, pág. 53, nota 26; PERUCCHI, "Algunos aspectos jurídicos del contrato de reaseguro", op. cit., pág. 115. En contra: MORALES SEGURA, op. cit, pág. 52. 
El lugar de localización del riesgo se ha considerado como la conexión más estrecha en el contrato de reaseguro. Si se concibe al reaseguro como un seguro de daños que cubre el riesgo de una deuda que nace en el patrimonio del reasegurado a consecuencia de la obligación por él asumida como asegurador en un contrato de seguro, la única localización del riesgo es el lugar del establecimiento del asegurador-reasegurado. El riesgo no puede ser identificado con el cubierto en el contrato de seguro directo, sino que es específico: una deuda eventual en el patrimonio del asegurador producida por la producción de un siniestro cuyo riesgo cubría el contrato de seguro directo. ${ }^{67}$

En suma, propiciamos que en el ámbito de aplicación de la Convención de México de 1994, en ausencia de elección del derecho aplicable, se interprete que el contrato de reaseguro se rige por la ley del establecimiento del reasegurado, porque en ese país se localiza el riesgo y porque se trata del mercado afectado por la operación y por lo tanto constituye el derecho con el cual el contrato presenta los vínculos más estrechos (art. 9).

\section{2.- Tratados de Montevideo de 1940}

Argentina se encuentra vinculada por el sistema del Tratado de Derecho Civil Internacional de Montevideo de 1940, con Paraguay y Uruguay. El Tratado de 1940, adopta en materia de contratos, en forma prioritaria la ley del lugar de cumplimiento (art. 37) y subsidiariamente la del lugar de celebración (art. 40).

Consideramos que las normas de conflicto sobre seguros no resultan aplicables al reaseguro, por lo que dejamos de lado el art. 12 del Tratado de Derecho Comercial Terrestre Internacional de Montevideo de 1940 y los arts. 28 y 29 del Tratado de Navegación Comercial Intemacional de Montevideo de 1940.

Si acudimos al principio general del lugar de cumplimiento establecido en el art. 37 del Tratado de Derecho Civil Internacional de Montevideo de 1940 debemos determinar en cuál de las calificaciones de lugar de cumplimiento contenidas en el art. 38 del mismo Tratado encuadra el contrato de reaseguro.

Descartamos los supuestos referidos a los contratos que recaen sobre cosas, y encuadramos al reaseguro como un contrato sobre prestación de servicios.

La asunción del riesgo, como prestación caracterís tica del contrato de reaseguros puede considerarse que se relaciona con un lugar especial, que es el establecimiento del reasegurado, lugar donde éste deberá cubrir el riesgo de una deuda que nace en su patrimonio a consecuencia de la obligación por él asumida como asegurador en un contrato de seguro (art. 38, última parte, inc. b).

Como ya lo hemos señalado, el riesgo en el contrato de reaseguro no puede ser identificado con el cubierto en el contrato de seguro directo, sino que es específico del

${ }^{67}$ FERNANDEZ ROZAS y SANCHEZ LORENZO, op, cit., págs. 54-55. 
contrato de reaseguro: la deuda eventual en el patrimonio del asegurador que se generaría por la producción de un siniestro cuyo riesgo cubre el contrato de seguro directo.

Por lo contrario, si no consideramos relacionado el reaseguro con un "lugar especial" (art. 38, última parte, inc. b) del Tratado de Derecho Civil Internacional de Montevideo de 1940), corresponderá aplicar la norma residual que se refiere al "domicilio del deudor al tiempo de la celebración del contrato", que conduce a la aplicación de la ley del domicilio del reasegurador, como deudor de la prestación de servicios (art. 38, última parte, inc. c) del mismo Tratado.

Pensamos que es muy preferible seguir la primera interpretación y regir el contrato de reaseguro por la ley del domicilio del reasegurado, por aplicación de los arts. 37 y 38 inc. b del Tratado de Derecho Civil Internacional de Montevideo de 1940.

\section{3.- Tratados de Montevideo de 1889}

Argentina aplica el Tratado de Derecho Civil Intemacional de Montevideo de 1889, en los contratos internacionales vinculados con Bolivia, Colombia y Perú. Si consideramos que las normas de conflicto sobre seguros no resultan aplicables al reaseguro y dejamos de lado los arts. 8, 9 y 6 del Tratado de Derecho Comercial Intemacional de Montevideo de 1889, debemos acudir al principio general del lugar de cumplimiento establecido en el art. 33 del Tratado de Derecho Civil Internacional de Montevideo de 1889.

Dado que las calificaciones de lugar de cumplimiento contenidas en el art. 34 del Tratado de Derecho Civil Internacional de Montevideo de 1889 son idénticas a las contenidas en el art. 38 del Tratado de 1940, encuadramos el contrato de reaseguro como contrato de prestación de servicios cuya eficacia se relaciona con un lugar especial, que es el domicilio de asegurador - reasegurado, por lo que aplicamos al contrato de reaseguro la ley del domicilio del reasegurado, al igual que en el Tratado de 1940.

Lamentablemente no existe jurisprudencia sobre la aplicación de los Tratados de Montevideo de 1889 y de 1940 en materia de reaseguro. Tampoco los autores de Derecho Internacional Privado se han detenido a analizar la ley aplicable al reaseguro, ni en los sistemas de fuente interna, ni en el ámbito de los Tratados de Montevideo. ${ }^{68}$

\section{4.- Sistema de fuente interna argentino}

a) Coordinación de los arts. 1205, 1209 y 1210 del Código Civil

No existen otros tratados que se refieran a contratos internacionales en que Argentina sea parte, por lo que las relaciones jurídicas con el resto de los países del mundo

${ }^{68}$ BOGGIANO, op. cit., tomo Il, págs. 571-572 trata la ley aplicable al contrato de seguro, pero no se refiere al reaseguro. 
quedarán sometidas al sistema de Derecho Internacional Privado de fuente interna, contenido básicamente en los arts. 1205 a 1214 del Código Civil argentino.

El art. 1205 somete a la ley del lugar de celebración los contratos hechos fuera del territorio de la República. En cambio, de los arts. 1209 y 1210 resulta que los contratos internacionales se rigen por la ley del lugar de cumplimiento. La contradicción existente ha tratado de superarse a través de dos interpretaciones elaboradas por la doctrina, que intentan construir un sistema normativo coherente para los contratos internacionales.

Alberto Juan Pardo sostiene que el principio general está contenido en los arts. 1209 y 1210 del Código Civil y que el art. 1205 es una norma subsidiaria. Los contratos se rigen por la ley del lugar de cumplimiento y sólo cuando éste no esté determinado, ni pueda determinarse con las pautas de los arts. 1212 y 1213 del Código Civil, deberá aplicarse la ley del lugar de celebración. ${ }^{69}$

Las enseñanzas de Pardo desde la cátedra no han sido estériles, pues Horacio Grigera Naón, ha desarrollado el mismo criterio. Considero un deber de honestidad intelectual recordar la interpretación de Alberto J. Pardo, que comparto, a pesar de que no haya sido plasmada en papel por su autor. ${ }^{70}$

La otra interpretación ha sido expuesta por Goldschmidt y seguida por Kaller de Orchansky y Boggiano. Se apoya en el texto literal de los artículos y sostiene que cuando el contrato tiene contacto argentino - ya sea que el lugar de celebración o el lugar de cumplimiento se encuentren en Argentina - se aplican las reglas de los arts. 1209 y 1210 del Código Civil y el contrato se rige por la ley del lugar de cumplimiento.

Cuando el contrato no tiene contacto con nuestro país, es decir cuando el lugar de cumplimiento y el lugar de celebración se encuentran en el extranjero, se aplica la norma del art. 1205 del Código Civil y por lo tanto el contrato se rige por la ley del lugar de celebración. ${ }^{71}$

No comporto esta postura, pues no encuentro razón para que un juez argentino aplique a la gran mayoría de los contratos internacionales la ley del lugar de cumplimiento y sin embargo utilice la del lugar de celebración cuando el contrato no tiene ningún contacto con nuestro país.

Hay que destacar que en la práctica las diferencias no son significativas según una u otra interpretación. Es que habitualmente los tribunales argentinos entienden en contratos internacionales que tienen contacto argentino, por lo que se utilizan los arts. 1209 y $1210 \mathrm{del}$ Código Civil, que conducen a la aplicación de la ley del lugar de cumplimiento.

\footnotetext{
${ }^{69}$ PARDO, Alberto Juan, sus clases de Derecho Internacional Privado en la Facultad de Derecho y Ciencias Sociales de la Universidad de Buenos Aires, entre 1980 y 1982.

70 GRIGERA NAON, Horacio A. "Autonomía contractual y derecho aplicable" en Revista del Derecho Comercial y de las Obligaciones, Buenos Aires, Depalma, 1989, año 22, págs. 409-462, especialmente p. 450.

7 GOLDSCHMIDT, op. cit, no 315, págs. 393-397; KALLER de ORCHANSKY, Berta Manual de Derecho Internacional Privado, Buenos Aires, Plus Uitra, 1976, págs. 383-389; ídem, Nuevo Manual de Derecho Internacional Privado, Buenos Aires, Plus Ultra, 1990, págs. 356-362; BOGGIANO, Antonio, op. cit., t. 2, págs. 282-283.
} 


\section{b) Lugar de cumplimiento: la prestación característica}

Los contratos bilaterales o sinalagmáticos no tienen un solo lugar de cumplimiento, sino que normalmente la obligación principal de una de las partes se cumplirá en un país y la de la otra parte en otro. ¿Cuál es, entonces, el lugar de cumplimiento que debe considerarse para determinar la ley aplicable al contrato?

Los arts. 1212 y 1213 contienen calificaciones del punto de conexión lugar de cumplimiento, pero siempre aluden a un lugar de cumplimiento o nombran al deudor, sin precisar a cuál de las dos partes del contrato refieren. No solucionan la cuestión sobre cuál de las dos obligaciones principales es la que debe tomarse en consideración para determinar la ley aplicable.

La doctrina y la jurisprudencia han adoptado la teoría de la prestación característica. Se considera característica aquella prestación que tipifica el contrato, esto es, que hace que sea una compraventa y no una locación de cosas. La obligación del vendedor: entrega de la cosa y la obligación del locador: mantenimiento en el uso y goce de la cosa locada, son las prestaciones características de estos contratos. Normalmente el pago del precio no es la prestación característica, pues es común a muchos contratos, por lo que no permite tipificarlos. ${ }^{72}$

La jurisprudencia argentina ha acogido las soluciones de la teoría de la prestación característica, a veces refiriéndose a ella en forma expresa y otras veces sin nombrarla. ${ }^{73}$

La teoría es entendida por algunos como referida al lugar donde físicamente se cumple la prestación y por otros como aludiendo al domicilio o a la residencia habitual o al establecimiento de la parte deudora de la prestación característica. ${ }^{74}$

En Argentina, Werner Goldschmidt han interpretado que la prestación característica indica la ley donde se cumple físicamente esa obligación ${ }^{75}$ y ese criterio fue seguido en el fallo del Juzgado Nacional de Paz n⿳⺈ 46, del 7 de octubre de 1969, firme, «Estudios Espíndola c/Bollati, Cristobal J.» ${ }^{76}$

Por lo contrario, Antonio Boggiano y María Susana Najurieta aluden al domicilio del deudor de la prestación característica. ${ }^{7 ?}$

Los arts. 1212 y 1213 del Código Civil argentino contienen calificaciones autárquicas para determinar el lugar de cumplimiento de los contratos internacionales, que deben ser

\footnotetext{
72 Sobre la teoría de la prestación caracteristica en Argentina ver: BOGGIANO, A. op. cit., t. II, págs. 280-281; GOLDSCHMIDT, op. cit., n² 315, pág. 395; NAJURIETA, María Susana «EI domicilio del deudor de la prestación característica en los contratos multinacionales" en Revista Doctrina Judicial, Buenos Aires, 1985-I, págs. 287-293, quien comenta varios fallos argentinos sobre el tema; VI Jornadas Nacionales de Derecho Civil, Santa Fe, 1977 en Conclusiones de Congresos..., op. cit., p. 29.

${ }^{73} \mathrm{Cám}$. Nac. Com., sala E, 10 de octubre de 1985 "Espósito e Hijos S.R.L., Antonio c/ Jocqueviel de Vieu» en Revista La Ley, Buenos Aires, t. 1986-D, págs. 46-51.

${ }^{74} \mathrm{El}$ criterio mencionado en segundo término es el utilizado por el art. 4.2. de la Convención de Roma de 1980 y por el art. 117 de la ley suiza de Derecho Internacional Privado del 18 de diciembre de 1987.

${ }^{75}$ GOLDSCHMIDT, op. cit., nº 315, pág. 395.

${ }^{76}$ Revista El Derecho, Buenos Aires, t. 33, pág. 26

${ }^{77}$ BOGGIANO, op. cit., t. II, pág.. 280-281 y págs. 620-623; NAJURIETA, María Susana "El domicilio del deudor...", op. cit., pág. 293.
} 
interpretadas en el sentido de que se define el lugar de cumplimiento de la prestación característica. Los criterios que dan estas normas pueden ordenarse de este modo:

1. Lugar designado por las partes (art. 1212).

2. Lugar determinado por la naturaleza de la obligación (art. 1212).

3. Lugar de celebración del contrato, si coincide con el domicilio del deudor (art. 1212).

4. Domicilio actual del deudor (art. 1213).

Dejamos de lado un análisis detallado del art. 1205 del Código Civil que somete a la ley del lugar de celebración del contrato, aquellos contratos que carecen de lugar de cumplimiento determinado o determinable y del art. 1214 del Código Civil argentino que se refiere a los contratos que no tienen lugar de cumplimiento, ni lugar de celebración: la norma dispone que los efectos del contrato, esto es las obligaciones de cada una de las partes, se regirán por la ley de su respectivo domicilio.

Es que para regir el contrato de reaseguro no es necesario acudir a la ley del lugar de celebración, ni al fraccionamiento previsto en el art. 1214 del Código Civil.

\section{c) Aplicación de las normas generales al contrato de reaseguro}

La determinación de la prestación característica en el contrato de reaseguro no es pacífica en el derecho comparado, como tampoco la individualización del derecho con el cual el contrato presenta los vínculos más estrechos.

Ninguno de los autores argentinos que se dedican al Derecho Internacional Privado ha dedicado una línea al contrato de reaseguro. No existe jurisprudencia que se haya pronunciado sobre el tema: las pocas sentencias dictadas en Argentina en materia de reaseguro, no han tratado la ley aplicable al contrato.

Los especialistas en Derecho de Seguros se han inclinado por aplicar la ley del domicilio del reasegurado. Peruchi afirma que si se califica al contrato de reaseguro como un seguro de responsabilidad, tiene por objeto mantener indemne al patrimonio del asegurado (asegurador-cedente) por los ataques que reciba de un tercero y por lo tanto es claro que el mismo se ejecuta en el mismo lugar donde se encuentra el patrimonio del asegurador cedente que debe proteger. Considera por ende aplicable la ley del domicilio del asegurador - cedente, en su caso la de su domicilio principal o social. ${ }^{78}$

El Proyecto de reforma del título II de la ley 17.418 sobre contrato de reaseguro de 1993, elaborado por Juan Carlos Morandi, Eduardo R. Steinfeld, Héctor Perucchi, Norberto J. Pantanali y Enrique Quintana, contemplaba también la aplicación de la ley del domicilio

\footnotetext{
78 PERUCCHI "Derecho de reaseguros", op. cit., pág. 8; PERUCCHI "Algunos aspectos jurídicos...", op. cit., págs. 115-116. Comparte nuestra postura LOPEZ SAAVEDRA, Domingo M. "Contrato de reaseguro: ley aplicable y jurisdicción", en Revista La Ley, Buenos Aires, 12 de junio de 1998, págs. 1-3. El autor mencionado sigue otras opiniones expresadas en la versión originaria de este trabajo "Derecho aplicable y jurisdicción competente en el contrato de reaseguro", que fue concluida en noviembre de 1997, al punto que lo cita, aunque sólo en las notas 27 y 43.
} 
del reasegurado, con la salvedad de que no autorizaba la autonomía de la voluntad. ${ }^{79}$

La Exposición de Motivos del Proyecto explicaba que el contrato de reaseguro se ejecuta en el lugar donde el asegurador cedente se encuentra autorizado a operar y consecuentemente expone su patrimonio, pues es ese patrimonio el que resulta objeto de la protección de indemnidad, cuando es afectado, en su medida por un siniestro indemnizable al asegurado. ${ }^{80}$

Apoyamos la aplicación de la ley del domicilio o establecimiento del aseguradorreasegurado al contrato de reaseguro, cuando no se haya pactado la aplicación de otra ley al contrato.

La determinación de la ley aplicable al reaseguro, ya sea por autonomía de la voluntad de las partes o por remisión de las normas de conflicto, es necesaria, aún cuando las partes pacten una cláusula arbitral, pues los árbitros pueden resolver la cuestión por equidad solamente cuando las partes así lo han convenido, de lo contrario deberán dictar su laudo de acuerdo a derecho, tal como lo disponen todos los reglamentos de arbitraje internacional y la Ley Modelo de UNCITRAL de $1985 .{ }^{81}$

Aunque resulten aplicables las cláusulas contractuales y los usos del comercio internacional, en oportunidades será necesario acudir a una ley aplicable al contrato, pues no todas las cuestiones pueden ser previstas en el contrato, ni se encuentran reguladas por los usos del comercio internacional.

\section{VI.- RECONOCIMIENTO Y EJECUCIÓN DE SENTENCIAS EXTRANJERAS}

\section{Tratados internacionales}

Argentina es parte en varios tratados internacionales multilaterales y bilaterales en materia de reconocimiento de sentencias extranjeras. Entre los países del Mercosur se ha elaborado el Protocolo de Cooperación y Asistencia Jurisdiccional en Materia Civil, Comercial, Laboral y Administrativa, suscripto en Las Leñas, el 27 de junio de $1992^{82}$, que ya hemos mencionado, que aborda en sus arts. 18 a 26 el reconocimiento y ejecución de las sentencias entre los países del Mercosur.

\footnotetext{
79 El art. 161 del Proyecto, no sancionado, dispone: En los contratos de reaseguro on que sea parte un asegurador cedente autorizado a operar en el pais, la ley aplicable será la argentina En los casos de reaseguros activos, incluidas las retrocesiones en los que sea parte un reasegurador radicado en el exterior, las partes podrán elegir la ley aplicable, que en caso de ser extranjera, tendrá que sujetarse a lo dispuesto por el art. 14 del Código Civil.

so MORANDI y otros "Modificación...", op. cit., págs. 173-174.

3t Ley Modelo de UNCITRAL: art. 28. Reglas de procedimiento de la C.C.I. vigente desde el 1 de enero de 1998: art. 17.3. Reglamento de CIAC, vigente desde el 1 de noviembre de 1996: art. 33. En sentido contrario: FRANCO TORTORA, Silvia Beatriz "Legislación del contrato de reaseguro...", op. cit., págs. 155-156.
}

82 ARGERICH, op. cit, págs. 8-13. 
Argentina es también parte en la Convención Interamericana sobre Eficacia Extraterritorial de las Sentencias y Laudos Arbitrales Extranjeros, suscripta en Montevideo, 1979, en el marco de la CIDIP - II, aprobada por Argentina por ley 22.921. La vigencia del Protocolo de Las Leñas de 1992 no impide la aplicación de la Convención Interamericana, entre los países del Mercosur, cuando esta resulte más favorable a la cooperación internacional.

El Tratado de Derecho Procesal Internacional de Montevideo de 1940, que regula en sus arts. 3 a 10 el tema, ha dejado de tener aplicación pues los tres Estados parte en el mismo, Argentina, Paraguay y Uruguay, son ratificantes de la Convención Interamericana.

En cambio el Tratado de Derecho Procesal Internacional de Montevideo de 1889, que enfoca el reconocimiento de sentencias y laudos extranjeros en sus arts. 3 a 8, debe ser aplicado por Argentina, Colombia, Paraguay, Perú y Uruguay con relación a Bolivia y viceversa.

Argentina ha aprobado unos pocos tratados bilaterales en materia de reconocimiento de sentencias extranjeras, con países europeos.

Argentina y Francia han firmado la Convención sobre Cooperación Judicial, en París, en 1991, aprobada por ley 24.107. Con Italia, se aplica la Convención sobre Asistencia Judicial y de reconocimiento y ejecución de sentencias en materia civil, suscripta en Roma el 10 de diciembre de 1987, (arts. 21 a 25), aprobada por ley 23.720.83

A pesar de la intensidad del tráfico jurídico entre España y Argentina, no existe un convenio internacional sobre la materia que vincule a ambos países.

\section{2.- Sistema de fuente interna}

En cuanto al sistema de fuente interna, hay en Argentina tantas regulaciones sobre reconocimiento de sentencias extranjeras como provincias existen, ya que el sistema federal reserva a las provincias el dictado de los códigos procesales, en virtud de lo dispuesto por el art. 75 inc. 12 de la Constitución Nacional, reformada en 1994, que corresponde al art. 67 inc. 11 de la Constitución de 1853-1860.

El Código Procesal Civil y Comercial de la Nación, que se aplica en la ciudad de Buenos Aires y en los tribunales federales de todo el país, regula la materia en los arts. 517 a 519.84

83 Sobre la Convención con Italia ver: NAJURIETA, María Susana "Reconocimiento y ejecución de sentencias en materia civil entre la República Argentina y la República Italiana (Convención aprobada por ley 23,720)", en Revista El Derecho, Buenos Aires, 1991, tomo 141, págs. 929-948. ${ }^{84}$ GOLDSCHMIDT, op. cit, parágr. 368-376, págs. 481-496; BOGGIANO, op. cit., tomo I, págs. 549-573; WEINBERG de ROCA, op. cit págs. 55-95; SOSA, Gualberto Lucas "Cooperación judicial internacional en el proceso civil. Un enfoque desde la realidad normológica y sociológica argentina", en Revista del Colegio de Abogados de La Plata, La Plata, Argentina, año XXXVI, 1997, vol. 57. 
En líneas generales, tanto en los tratados internacionales como en las normas de fuente interna, se exigen los clásicos requisitos formales de autenticidad y traducción, los procesales, referidos a la jurisdicción indirecta, notificación al demandado, garantía de defensa en juicio y cosa juzgada y como único requisito de fondo, que no se encuentre comprometido el orden público internacional.

En ningún caso se realiza una revisión de fondo de la sentencia. Tampoco se exige reciprocidad, con excepción del Código de Procedimientos en lo Civil y Comercial de la Provincia de Santa Fe, ley provincial 5531 de 1962 (arts. 269 a 271).

La existencia de una sentencia argentina o de un proceso en trámite en la Argentina, sobre la misma cuestión objeto de la sentencia extranjera, permite oponer las excepciones de cosa juzgada o litispendencia, que en algunas fuentes normativas se señala en forma expresa, por ejemplo art. 517 inc. $5^{\circ}$ del Código Procesal Civil y Comercial de la Nación, y en otras no, pero es el criterio imperante en la doctrina y jurisprudencia. ${ }^{85}$

La ejecución de sentencias extranjeras en Argentina se solicita ante el juez de primera instancia que corresponda en razón de la materia y el trámite que se imprime es el de los incidentes (art. 518 del Código Procesal Civil y Comercial de la Nación), es decir que se confiere traslado al demandado por cinco días (art. 180 del mismo Código).

\section{VII.- RECONOCIMIENTO Y EJECUCIÓN DE LAUDOS ARBITRALES EXTRANJEROS}

\section{Tratados internacionales}

Ya nos hemos referido a la Convención sobre el Reconocimiento y la Ejecución de las Sentencias Arbitrales Extranjeras, suscripta en Nueva York el 10 de junio de 1958, a la Comvención Interamericana sobre Arbitraje Comercial Intemacional. suscripta en Panamá el 30 de enero de 1975, al Protocolo de Cooperación y Asistencia Jurisdiccional en Materia Civil, Comercial, Laboral y Administrativa, suscripto en Las Leñas, el 27 de junio de $1992^{86}$ y a la Comvención Interamericana sobre Eficacia Extraterritorial de las Sentencias y Laudos Arbitrales Extranjeros, suscripta en Montevideo el 8 de mayo de $1979 .{ }^{87}$ Dentro de sus respectivos ámbitos de aplicación, estos tratados internacionales rigen la ejecución de los laudos arbitrales extranjeros.

Entre los países del Mercosur, los requisitos para solicitar el reconocimiento y la ejecución de los laudos arbitrales se rigen básicamente por la Convención de Panamá de 1975 y en todo lo que no esté previsto en ella, por el Protocolo de Las Leñas de $1992 .{ }^{88} \mathrm{El}$

\footnotetext{
$\overline{85}$ GOLDSCHMIDT, op. cit., parágr. 370, págs. 487.

${ }^{86}$ Ver punto III.

${ }^{87}$ Ver punto $\mathrm{VI}$.

ש8 NOODT TAQUELA "Arbitraje internacional entre particulares...", op. cit., págs. 713; NOODT TAQUELA, Maria Blanca "La contratación mercantil en el Mercosur", en Jornadas UruguayasSantafesinas. 2da. etapa. Libro de Ponencias, Santa Fe, Universidad Nacional del Litoral, Santa Fe, Argentina, Universidad de la República, Montevideo, Uruguay, 1997, págs. 263-271, espec. pág. 268.
} 
trámite puede efectuarse por exhorto, a través de Autoridad Central y sin necesidad de legalización ni apostille (arts. 19 y 26 del Protocolo de Las Leñas).

La Convención de Panamá es igualmente aplicable con otros 12 países americanos y podrá ser complementada, en su caso, con la Convención Interamericana sobre Eficacia extraterritorial de las sentencias y laudos arbitrales extranjeros, Montevideo de 1979.

La Convención de Nueva York de 1958 tiene un carácter subsidiario (art. VII) con relación a la Convención de Panamá de 1975, por lo que será aplicable a los laudos dictados en países que no sean ratificantes de la Convención Interamericana. Argentina hizo la declaración prevista en la Convención por lo que sólo la aplica a condición de reciprocidad, es decir con relación a laudos arbitrales dictados en países ratificantes.

\section{2.- Sistema de fuente interna}

Los laudos arbitrales dictados en países con los cuales Argentina no está vinculada por ningún tratado internacional, serán también reconocidos y ejecutados, aplicándose los requisitos para el reconocimiento de las sentencias extranjeras, como lo indica el art. 519 bis del Código Procesal Civil y Comercial de la Nación.

El mismo Código (art. 1) autoriza los acuerdos arbitrales, incluso a favor de árbitros que actúen en el extranjero si se trata de asuntos patrimoniales de carácter internacional, en tanto no exista jurisdicción argentina exclusiva, ni la prórroga esté prohibida por la ley. El sistema de fuente interna argentino no limita el arbitraje a las cuestiones de naturaleza mercantil, sino que se lo permite en general en los asuntos patrimoniales.

El reaseguro es susceptible de ser sometido a arbitraje, ya que el art. 57 de la ley 17.418 que prohibe las cláusulas compromisorias en materias de seguros, se ha considerado inaplicable al reaseguro. ${ }^{89}$

${ }^{89}$ FRANCO TORTORA "Arbitraje..., op. cit., págs. 32-33; MORANDI y otros "Modificación..., op. cit., pág. 175. 